\title{
Lower export production during glacial periods in the equatorial Pacific derived from $\left({ }^{231} \mathrm{~Pa} /{ }^{230} \mathrm{Th}\right)_{\mathrm{xs}, 0}$ measurements in deep-sea sediments
}

\author{
Sylvain Pichat, ${ }^{1,2,3,4}$ Kenneth W. W. Sims,${ }^{5}$ Roger François, ${ }^{6}$ Jerry F. McManus, ${ }^{5}$ \\ Susan Brown Leger, ${ }^{6}$ and Francis Albarède ${ }^{1}$
}

Received 27 November 2003; revised 4 September 2004; accepted 30 September 2004; published 16 December 2004.

[1] The $\left({ }^{231} \mathrm{~Pa}{ }^{230} \mathrm{Th}\right)_{\mathrm{xs}, 0}$ records obtained from two cores from the western (MD97-2138; $1^{\circ} 25^{\prime} \mathrm{S}, 146^{\circ} 24^{\prime} \mathrm{E}$, $1900 \mathrm{~m}$ ) and eastern (Ocean Drilling Program Leg 138 Site 849, $0^{\circ} 11.59^{\prime} \mathrm{N}, 110^{\circ} 31.18^{\prime} \mathrm{W}, 3851 \mathrm{~m}$ ) equatorial Pacific display similar variability over the last 85,000 years, i.e., from isotopic stages 1 to $5 \mathrm{a}$, with systematically higher values during the Holocene, isotopic stage 3, and isotopic stage 5a, and lower values, approaching the production rate ratio of the two isotopes (0.093), during the colder periods corresponding to isotopic stages 2 and 4 . We have also measured the ${ }^{230}$ Th-normalized biogenic preserved and terrigenous fluxes, as well as major and trace elements concentrations, in both cores. The $\left({ }^{231} \mathrm{~Pa} /{ }^{230} \mathrm{Th}\right)_{\mathrm{xs}, 0}$ results combined with the changes in preserved carbonate and opal fluxes at the eastern site indicate lower productivity in the eastern equatorial Pacific during glacial periods. The $\left({ }^{231} \mathrm{~Pa} /{ }^{230} \mathrm{Th}\right)_{\mathrm{xs}, 0}$ variations in the western equatorial Pacific also seem to be controlled by productivity (carbonate and/or opal). The generally high $\left({ }^{231} \mathrm{~Pa} /{ }^{230} \mathrm{Th}\right)_{\mathrm{xs}, 0}$ ratios $(>0.093)$ of the profile could be due to opal and/or $\mathrm{MnO}_{2}$ in the sinking particles. The profiles of $\left({ }^{231}{ }^{\mathrm{Pa} /}{ }^{230} \mathrm{Th}\right)_{\mathrm{xs}, 0}$ and ${ }^{230} \mathrm{Th}$ normalized fluxes indicate a decrease in exported carbonate, and possibly opal, during isotopic stages 2 and 4 in MD97-2138. Using ${ }^{230}$ Th-normalized flux, we also show that sediments from the two cores were strongly affected by sediment redistribution by bottom currents suggesting a control of mass accumulation rates by sediment focusing variability. INDEX TERMS: 4231 Oceanography: General: Equatorial oceanography; 4267 Oceanography: General: Paleoceanography; 4825 Oceanography: Biological and Chemical: Geochemistry; 4860 Oceanography: Biological and Chemical: Radioactivity and radioisotopes; 4863 Oceanography: Biological and Chemical: Sedimentation; KEYWORDS: $\left({ }^{231} \mathrm{~Pa} /{ }^{230} \mathrm{Th}\right)_{\mathrm{xs}, 0}$, export productivity, Pacific

Citation: Pichat, S., K. W. W. Sims, R. François, J. F. McManus, S. Brown Leger, and F. Albarède (2004), Lower export production during glacial periods in the equatorial Pacific derived from $\left({ }^{231} \mathrm{~Pa} /{ }^{230} \mathrm{Th}\right)_{\mathrm{xs}, 0}$ measurements in deep-sea sediments, Paleoceanography, 19, PA4023, doi:10.1029/2003PA000994.

\section{Introduction}

[2] Increasing evidence for significant sea surface cooling in the tropical ocean during glacial periods [Rosenthal et al., 2003; Visser et al., 2004, and references therein] has lead to a resurgence of interest in the role played by the equatorial Pacific in Quaternary climatic cycles [e.g., Cane and Clement, 1999]. The equatorial Pacific is one of the most important sources of water vapor to the atmosphere and heat

${ }^{1}$ Laboratoire de Sciences de la Terre, Ecole Normale Supérieure de Lyon, Lyon, France.

${ }^{2}$ Also at Department of Geology and Geophysics, Woods Hole Oceanographic Institution, Woods Hole, Massachusetts, USA.

${ }^{3}$ Also at Department of Marine Chemistry and Geochemistry, Woods Hole Oceanographic Institution, Woods Hole, Massachusetts, USA. $\mathrm{UK}$.

${ }^{4}$ Now at University of Oxford, Department of Earth Sciences, Oxford,

${ }^{5}$ Department of Geology and Geophysics, Woods Hole Oceanographic Institution, Woods Hole, Massachusetts, USA.

${ }^{6}$ Department of Marine Chemistry and Geochemistry, Woods Hole Oceanographic Institution, Woods Hole, Massachusetts, USA.

Copyright 2004 by the American Geophysical Union. 0883-8305/04/2003PA000994 to higher latitudes. Its impact on global climate is underscored by the perturbations associated with El Nino/Southern Oscillation (ENSO) cycles. El Nino is initiated by an eastward displacement toward the central Pacific of the zone of warmest surface waters, called the western Pacific warm pool, and a weakening of the associated center of atmospheric convection. This shift results in a lower zonal sea surface temperature (SST) gradient that weakens the Trade Winds, decreases the equatorial upwelling and the zonal tilt of the thermocline. In addition, the displacement of the atmospheric convection center results in a global change in atmospheric circulation that synchronously affects climate in widespread regions of the globe. The system then swings back to the opposite phase (La Nina) with the warm pool moving and contracting westward, resulting in stronger Trade Winds, equatorial upwelling and zonal thermocline tilt.

[3] Building on these observations, it has been suggested that changes in incoming solar radiation controlled by orbital forcing could affect directly both the mean SST and the SST distribution in the equatorial Pacific, and change the frequency and intensity of ENSO. This, in turn, would affect global climate through atmospheric telecon- 
nection, as observed today during El Nino events. Changes in SSTs in the tropical Pacific could thus be one of the main drivers of climatic variations during the late Quaternary, particularly in the precessional frequency band [Cane, 1998; Clement et al., 1999]. Only a few studies have shown a precession-related signal in sediments from the equatorial Pacific [Beaufort et al., 2001; Koutavas et al., 2002; Pichat et al., 2003] therefore the significance of this forcing has still to be established. Past ENSO variability may not capture the full range of tropical climate variability on Milankovich timescales, and whether glacial periods were times of enhanced El-Nino or La Nina, or whether this analogy is even appropriate are still open questions.

[4] With the modern orbital configuration, direct observations indicate that El Nino warms the North American continent, while La Nina cools it [Cane, 1998]. It could thus be surmised that, if similar atmospheric teleconnections prevailed in the past, more frequent El Nino events would have promoted melting of the Laurentide ice sheet, while less frequent El Nino (or more prominent La Nina events) would have promoted ice buildup [Cane and Clement, 1999]. Predominance of La Nina conditions during glacial periods would be consistent with stronger Trade Winds, during these periods, as evidenced by aeolian dust grain size distribution [Parkin and Shackleton, 1973; Sarnthein et al., 1981] and numerical simulations [e.g., Bush and Philander, 1999]. Belying this simple inference, however, are model studies suggesting that solar forcing in the equatorial Pacific would instead promote El Nino-like conditions during glacial periods [Clement et al., 1999].

[5] Paleoceanographic evidence supporting either of these scenarios is still ambiguous. It is now recognized that SST in the equatorial Pacific was several degrees cooler during the last glacial maximum [Lea et al., 2000; Kienast et al., 2001; Stott et al., 2002; Rosenthal et al., 2003; Visser et al., 2004]. While earlier reports of lower glacial SST in the eastern equatorial Pacific (EEP) have been interpreted as reflecting higher equatorial upwelling rates, i.e., a La Ninalike system, it has also been recognized that cooling could arise from advection of cold water from the south [Lyle et al., 1992; Mix et al., 1999; Feldberg and Mix, 2003] or extratropical forcing [Andreasen et al., 2001]. Past changes in the strength of the Trade Winds and equatorial upwelling could be more confidently established from the zonal and latitudinal SST gradients in the equatorial Pacific. Lea et al. [2000] found a $\sim 3^{\circ} \mathrm{C}$ drop in SST both in the eastern and western Pacific, and a slightly larger zonal gradient during glacial periods. They also found evidence for lower salinity over the Ontong Java Plateau relative to the global ocean mean. Both these observations are attributed to a La Ninalike situation, which is also consistent with the steeper zonal tilt of the equatorial Pacific thermocline suggested by the data of Andreasen and Ravelo [1997]. However, Koutavas et al. [2002] found a smaller drop in glacial SST $\left(\sim 1^{\circ} \mathrm{C}\right)$ at a site further south in the EEP. When compared to the results obtained by Lea et al. [2000] further north and Kienast et al. [2001] in the South China Sea, Koutavas et al. [2002] results suggests weaker latitudinal and longitudinal SST gradients in the glacial equatorial Pacific and weaker upwelling, i.e., a dominance of El Nino. This interpretation, in turn, is consistent with the results of Stott et al. [2002] who found saltier surface waters in the Mindanao Sea, possibly reflecting the westward displacement of the center of atmospheric convection, which characteristically happens during El Nino events.

[6] The modern ENSO cycle affects primary production in the equatorial Pacific [Murray et al., 1994]. Reconstructing past changes in equatorial productivity could thus help establishing whether one ENSO mode (El Nino or La Nina) prevailed in the past, or whether neither of these climatic modes adequately describes the oceanography and atmospheric interactions of the glacial Earth. Because El Nino curtails equatorial upwelling, lower equatorial productivity is expected during periods when it becomes prominent. Accurate estimation of past changes in productivity is essential to fully describe and understand the oceanography of the equatorial Pacific during glacial periods and its impact on global climate. In addition to being a diagnostic help, the evolution of productivity in the tropical Pacific may have a direct impact on global climate by affecting atmospheric $\mathrm{CO}_{2}$. Changes in productivity and nutrient supply rate in the equatorial Pacific would have little direct effect on the atmospheric $\mathrm{CO}_{2}$, because all the nutrients upwelled at the equator are eventually utilized by phytoplankton in surface waters. However, changes in the ratio of silicate to nitrate supply, as suggested by Matsumoto et al. [2002] and Brzezinski et al. [2002], could significantly affect atmospheric $\mathrm{CO}_{2}$ by altering plankton assemblages, organic carbon to carbonate rain ratio and surface alkalinity.

[7] The importance of accurately reconstructing paleoproductivity in the equatorial Pacific has long been recognized and has resulted in sustained efforts over the last decades. Despite these efforts, a consensus has not yet been reached, even as to whether productivity was higher or lower during glacial periods. The more generally accepted view is that glacial productivity in the EEP was higher, supporting a La Nina-dominated glacial climate with stronger Trade Winds and higher upwelling rates. This inference is mainly based on accumulation rates of biogenic materials in the sediments of the equatorial Pacific [Pedersen, 1983; Pedersen et al., 1991; Lyle et al., 1988; Sarnthein et al., 1988; Paytan et al., 1996]. However, this view has recently been challenged. Variations in accumulation rates in the sediments of the equatorial Pacific appear to be primarily driven by sediment redistribution by bottom currents [Marcantonio et al., 2001; Loubere et al., 2004]. Instead, a new array of paleoproductivity tracers points to lower glacial productivity in the equatorial Pacific. For example, using a transfer function based on benthic foraminifera assemblages, Loubere [1999, $2000,2001,2003$ ] reports lower glacial productivity in the South Equatorial Current (SEC) region of the EEP (Figure 1), which is supplied with nutrients from the deeper part of the equatorial undercurrent (EUC). In contrast, this new tracer confirms higher glacial productivity in Panama Basin and at the southern edge of the SEC region. Lower glacial productivity in the SEC is also consistent with lower carbonate rain rates obtained by combining ${ }^{230} \mathrm{Th}$-normalized sedimentary carbonate fluxes and estimates of carbonate preservation [Loubere et al., 2004]. 


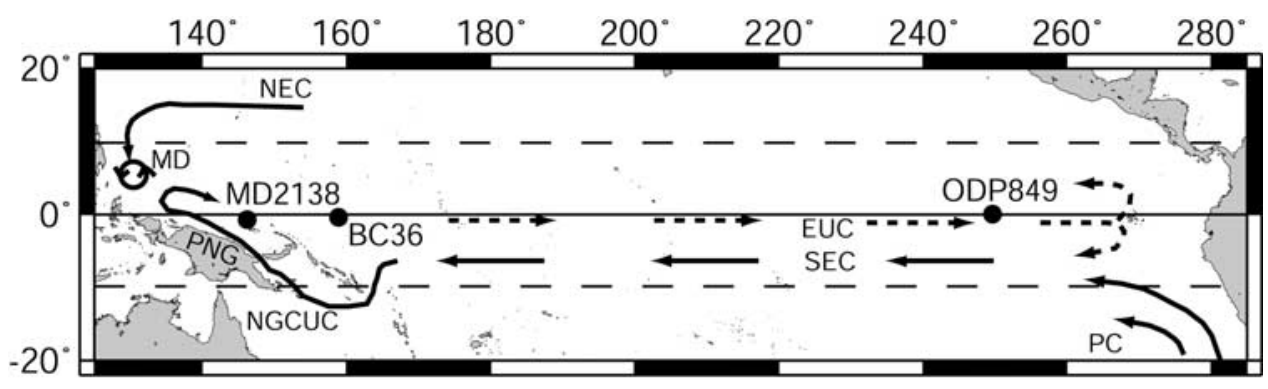

Figure 1. Cores location (black dots): ODP849 (Leg 138 Site $849,0^{\circ} 11.59^{\prime} \mathrm{N}, 110^{\circ} 31.18^{\prime} \mathrm{W}, 3851 \mathrm{~m}$ water depth) in the eastern equatorial Pacific, MD2138 $\left(1^{\circ} 25^{\prime} \mathrm{S}, 146^{\circ} 24^{\prime} \mathrm{E}, 1900 \mathrm{~m}\right.$ water depth) in the western part of the western Pacific warm pool and BC36 $\left(0.14^{\circ} \mathrm{S}, 158^{\circ} 57^{\prime} \mathrm{E}, 2311 \mathrm{~m}\right.$ water depth) on the Ontong Java Plateau. The main currents are also represented: north equatorial current (NEC), equatorial undercurrent (EUC), south equatorial current (SEC), Peru current (PC), Mindanao Dome (MD) and New Guinea coastal undercurrent (NGCU) originating from the SEC. PNG indicates the island of Papua New Guinea.

[8] To further examine glacial/interglacial productivity variability in the equatorial Pacific, we have measured ${ }^{231} \mathrm{~Pa},{ }^{230} \mathrm{Th},{ }^{232} \mathrm{Th},{ }^{235} \mathrm{U},{ }^{238} \mathrm{U}$, major and trace element concentrations at three sites (Figure 1). We have calculated the ${ }^{230}$ Th-normalized fluxes of biogenic (carbonate and opal) and terrigenous material and the ${ }^{231} \mathrm{~Pa}$ to ${ }^{230} \mathrm{Th}$ excess activity ratio, decay corrected to the time of deposition (hereafter referred to as $\left.\left({ }^{231} \mathrm{~Pa} /{ }^{230} \mathrm{Th}\right)_{\mathrm{xs}, 0}\right)$. The latter has been proposed as a proxy to assess changes in biological productivity of the ocean during the last 150-200 kyr [Lao et al., 1992; François et al., 1993, 1997; Kumar et al., 1993, 1995], even though its interpretation can sometimes be equivocal [e.g., Walter et al., 1999; Chase et al., 2002, 2003a]. The advantage of the $\left({ }^{231} \mathrm{~Pa} /{ }^{230} \mathrm{Th}\right)_{\mathrm{xs}, 0}$ proxy is its insensitivity to remineralization, dilution and sediment redistribution. As yet, only a few studies [Lao et al., 1992; Stephens and Kadko, 1997; Berelson et al., 1997] have used this proxy to investigate productivity variations during the Quaternary in the Pacific.

\section{Principles Underlying the Use of $\left({ }^{230} \mathrm{Th}\right)_{\mathrm{xs}, 0}$ Normalization and $\left({ }^{231} \mathrm{~Pa} /{ }^{230} \mathrm{Th}\right)_{\mathrm{xs}, 0}$ to Estimate Sedimentary Fluxes and Paleoproductivity}

[9] Uranium is homogeneously distributed in the ocean because of its long residence time (200-450 kyr [Brewer, 1975; Ku et al., 1977; Chen et al., 1986]), compared with the mixing time of the ocean (1000-1600 years [Broecker and Peng, 1982]). As a consequence, ${ }^{231} \mathrm{~Pa}\left(\mathrm{t}_{1 / 2}=32760\right.$ years $)$ and ${ }^{230} \mathrm{Th}\left(\mathrm{t}_{1 / 2}=75380\right.$ years $)$ are uniformly produced in the water column at a constant activity ratio of 0.093 (hereafter referred to as production rate ratio) from $\alpha$ decay of ${ }^{234} \mathrm{U}$ and ${ }^{235} \mathrm{U}$. Both ${ }^{230} \mathrm{Th}$ and ${ }^{231} \mathrm{~Pa}$ are extremely particle reactive, which leads to short residence times in the water column: $10-40$ years for ${ }^{230} \mathrm{Th}$ [Brewer et al., 1980; Nozaki et al., 1981; Huh and Beasley, 1987] and 50-200 years for ${ }^{231} \mathrm{~Pa}$ [Anderson et al., 1983b; Nozaki and Nakanishi, 1985; Yu et al., 1996]. With its higher particle reactivity and shorter residence time, ${ }^{230} \mathrm{Th}$ is almost totally scavenged from the water column by the vertical particle flux [Bacon and Rosholt, 1982; Anderson et al., 1983a, 1983b; Bacon, 1984]. As a result, the flux of scavenged ${ }^{230} \mathrm{Th}$ to the seafloor approximates its known production rate in the water column [Bacon, 1984; Henderson et al., 1999; Yu et al., 2001] and can be used as a reference to estimate sedimentary fluxes [Suman and Bacon, 1989; François et al., 1990; McManus et al., 1998; Frank et al., 1999; Chase et al., 2003b; François et al., 2004].

[10] The total normalized flux or "rain rate" (RR) is given by:

$$
\mathrm{RR}=\frac{\beta z}{\left({ }^{230} \mathrm{Th}_{x s, 0}\right)},
$$

and the normalized flux for a component $\mathrm{i}\left(\mathrm{RR}_{i}\right)$, is given by

$$
\mathrm{RR}_{i}=\frac{\beta z f_{i}}{\left({ }^{230} \mathrm{Th}_{x s, 0}\right)},
$$

where $\beta$ is the constant production rate of ${ }^{230} \mathrm{Th}$ from ${ }^{234} \mathrm{U}$ in the water column, $\beta=2.63 \mathrm{dpm} / \mathrm{cm}^{2} / \mathrm{ka}$ per $\mathrm{km}$ of water depth; $\mathrm{z}$ is water depth, $\mathrm{km}$; and $\mathrm{f}_{\mathrm{i}}$ is the weight fraction of sedimentary constituent i. $\left({ }^{230} \mathrm{Th}_{\mathrm{xs}, 0}\right)$ is the activity of scavenged ${ }^{230} \mathrm{Th}$ corrected to the time of deposition, dpm $/ \mathrm{g}_{\text {sediment }}$.

[11] Because of its strong adsorption, scavenged ${ }^{230} \mathrm{Th}$ remains incorporated in sediment even if the particles that originally transported it to the seafloor are solubilized during early diagenesis. The "rain rates" calculated by normalizing to ${ }^{230} \mathrm{Th}_{\mathrm{xs}, 0}$ are thus "preserved" vertical fluxes, i.e., the vertical fluxes of material that reach the seafloor and remain after diagenetic remineralization.

[12] The focusing factor $(\psi)$ is the ratio of the inventory of ${ }^{230} \mathrm{Th}_{\mathrm{xs}, 0}$ between dated horizons and ${ }^{230} \mathrm{Th}$ produced in seawater over the corresponding time interval [Suman and Bacon, 1989]:

$$
\psi=\frac{\int_{r_{1}}^{r_{2}}\left({ }^{230} T h_{x s, 0}\right) \rho_{r} d r}{\beta z\left(t_{1}-t_{2}\right)},
$$


where $r_{i}$ is sediment depth, $\mathrm{cm} ; t_{i}$ is the corresponding age deduced from an independent chronology, ka; $\mathrm{z}$ is water depth, $\mathrm{km}$; and $\rho_{\mathrm{r}}$ is dry bulk density, $\mathrm{g} / \mathrm{cm}^{3}$.

[13] $\left({ }^{230} \mathrm{Th}_{\mathrm{xs}, 0}\right)$ and $\rho_{\mathrm{r}}$ are averaged between dated sediment horizons $\mathrm{r}_{\mathrm{i}} . \psi>1$ indicates that more ${ }^{230} \mathrm{Th}_{\mathrm{xs}, 0}$ has accumulated than produced in the overlying water column, thus indicating a lateral import of sediment to the area, i.e., a net sediment focusing, whereas $\psi<1$ indicates a net winnowing.

[14] ${ }^{231} \mathrm{~Pa}$ has a lower particle affinity than ${ }^{230} \mathrm{Th}$ and a longer residence time in the water column. As a result, ${ }^{231} \mathrm{~Pa}$ is more effectively transported over oceanic basinscale distances to be preferentially removed in areas of higher particle flux and higher scavenging intensity [Anderson et al., 1983b; Bacon, 1988; Yu et al., 2001]. This preferential removal, called boundary scavenging, results in $\left({ }^{231} \mathrm{~Pa} /{ }^{230} \mathrm{Th}\right)_{\mathrm{xs}, 0}>0.093$ in the sediments underlying regions with high particle flux, which in open ocean settings, often reflect higher export production $[\mathrm{Yu}$ et al., 2001]. If particle flux were the only factor controlling $\left({ }^{231} \mathrm{~Pa} /{ }^{230} \mathrm{Th}\right)_{\mathrm{xs}, 0}$ in deep-sea sediments, this tracer could be used as an unambiguous tracer of particle flux from which paleoproductivity could be inferred. Ambiguities arise, however, because $\left({ }^{231} \mathrm{~Pa} /{ }^{230} \mathrm{Th}\right)_{\mathrm{xs}, 0}$ is also affected by two other factors: (1) deep water circulation, which affects the lateral transport of ${ }^{231} \mathrm{~Pa}$ within and between ocean basins, and (2) particle composition, which influences the relative affinity of ${ }^{230} \mathrm{Th}$ and ${ }^{231} \mathrm{~Pa}$ for particles. The effect of deep water circulation is best exemplified by contrasting the increase in $\left({ }^{231} \mathrm{~Pa} /{ }^{230} \mathrm{Th}\right)_{\mathrm{xs}, 0}$ with particle flux in the Atlantic and Pacific ocean. Sediment trap experiments have shown that the $\left({ }^{231} \mathrm{~Pa} /{ }^{230} \mathrm{Th}\right)_{\mathrm{xs}}$ ratio is less sensitive to particle flux in the Atlantic than in the Pacific [Yu et al., 2001; Moran et al., 2002]. This difference has been attributed to the shorter residence time of deep water in the Atlantic (100 years [Broecker, 1979] versus 600 years in the Pacific [Stuiver et al., 1983]) which limits the establishment of lateral concentration gradients and prevents the full expression of boundary scavenging in the Atlantic [Yu et al., 1996]. Therefore a single relationship between $\left({ }^{231} \mathrm{~Pa} /{ }^{230} \mathrm{Th}\right)_{\mathrm{xs}, 0}$ and particle flux, valid for all the oceans, cannot be expected. Changes in particle composition further complicates the interpretation of sedimentary $\left({ }^{231} \mathrm{~Pa} /{ }^{230} \mathrm{Th}\right)_{\mathrm{xs}, 0}$. The $\left({ }^{231} \mathrm{~Pa} /{ }^{230} \mathrm{Th}\right)_{\mathrm{xs}, 0}$ of sediment and settling particles depends in part on their ferromanganese oxides [Kadko, 1980; Anderson et al., 1983b; Shimmield et al., 1986; Shimmield and Price, 1988; Frank et al., 1994] and biogenic opal [Walter et al., 1997, 1999, 2001; Chase et al., 2002, 2003a] content. Unlike the other constituents of marine particles, ferromanganese oxides have similar affinity for ${ }^{231} \mathrm{~Pa}$ and ${ }^{230} \mathrm{Th}$ and biogenic opal has a greater affinity for ${ }^{231} \mathrm{~Pa}$ than for ${ }^{230} \mathrm{Th}$. As a result, their increasing prominence in settling particles increases $\left({ }^{231} \mathrm{~Pa} /{ }^{230} \mathrm{Th}\right)_{\mathrm{xs}, 0}$ in the underlying sediment, independently of the particle flux. The effect of ferromanganese oxides is largely restricted to metalliferous sediments associated with hydrothermal plumes [Kadko, 1980; Shimmield and Price, 1988] or the recycling of reduced Mn from suboxic sediments [Shimmield and Price, 1988; Anderson et al., 1983b]. Discerning the effect of opal is more difficult because of poor and variable preservation. Thus opal concentration in sediment does not necessarily reflect opal content in settling particles that brought ${ }^{230} \mathrm{Th}$ and ${ }^{231} \mathrm{~Pa}$ to the seafloor. Using sediment trap samples ranging from opal-dominated to carbonate-dominated regions, Chase et al. [2002] found a strong correlation between the opal/carbonate ratio and the $\left({ }^{231} \mathrm{~Pa} /{ }^{230} \mathrm{Th}\right)_{\mathrm{xs}}$ of settling particles. However, within the equatorial Pacific region, where the variability of opal/carbonate ratio is smaller, $\left({ }^{231} \mathrm{~Pa} /{ }^{230} \mathrm{Th}\right)_{\mathrm{xs}}$ correlates better with particle flux than with particle composition. As a result, we are not able as yet to distinguish clearly between the relative importance of particle flux and particle composition in controlling $\left({ }^{231} \mathrm{~Pa} /{ }^{230} \mathrm{Th}\right)_{\mathrm{xs}, 0}$. Therefore observed past changes in sedimentary $\left({ }^{231} \mathrm{~Pa} /{ }^{230} \mathrm{Th}\right)_{\mathrm{xs}, 0}$ in the equatorial Pacific could reflect either changes in particle flux, or in the relative opal content of settling particles or both. To better constrain our observations, we have also measured the total, biogenic (opal and carbonate) and terrigenous ${ }^{230} \mathrm{Th}$ normalized fluxes, as well as concentrations of major and trace elements in the sediments.

\section{Experimental Section}

\subsection{Sediment Samples}

[15] Three cores located along the Equator have been analyzed in this study (Figure 1). Core MD97-2138 (hereafter referred to as MD2138) was collected using the CALYPSO Kullemberg giant piston corer aboard the R/V Marion Dufresne during campaign IMAGES III. The MD2138 site is situated at a depth of $1900 \mathrm{~m}$, north of Manus Island, $300 \mathrm{~km}$ north of Papua New Guinea, in the western part of the Western Pacific Warm Pool. ODP Leg 138 Site 849 cores (hereafter referred to as ODP849) are located in the eastern equatorial Pacific (EEP) in deeper water $(3800 \mathrm{~m})$ at about $850 \mathrm{~km}$ west of the East Pacific Rise. Core MW91-9 BC36, referred hereafter to as BC36, has been collected using a box corer during R/V Moana Wave cruise 9 on the Ontong Java plateau (2311 m water depth).

[16] All three cores are located above the carbonate compensation depth and far from any hydrothermal sources. ODP849 and BC36 are far from riverine sources of terrigenous material. For these two cores, particulate matter sinking through the water column is predominantly biogenic and winds are the only significant supplier of terrigenous material. On the contrary, MD2138 is located close to Papua New Guinea where large riverine discharges of terrigenous material occur [Milliman et al., 1999].

\subsection{Age Models and Stratigraphy}

[17] For ODP849, we used the age model of Mix et al. [1995] based on the comparison between $\delta^{18} \mathrm{O}$ record on benthic foraminifer $C$. wuellerstorfi and the SPECMAP stack [Imbrie et al., 1984]. For core MD2138, we used an age model based on six ${ }^{14} \mathrm{C}$ ages and the $\delta^{18} \mathrm{O}$ record of planktonic foraminifer G. ruber (T. de Garidel-Thoron, manuscript in preparation, 2004). For core BC36, we have used the $\delta^{18} \mathrm{O}$ records on planktonic foraminifer, P. obliquiloculata and G. sacculifer, from Patrick and 
nกำ

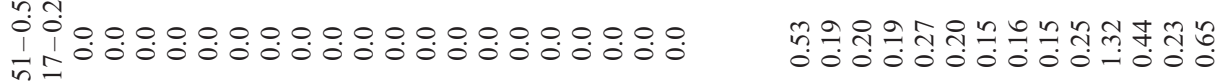

กำ

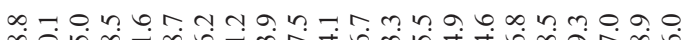

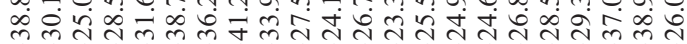

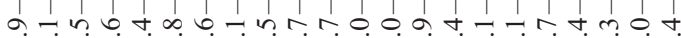

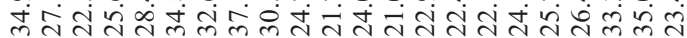

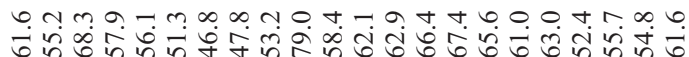
o b t n n m n n a

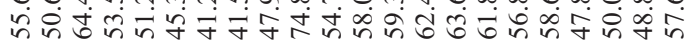

चं

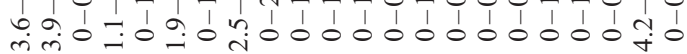

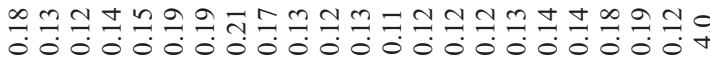

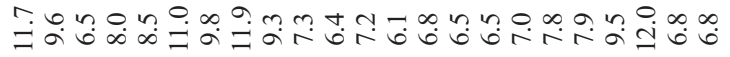

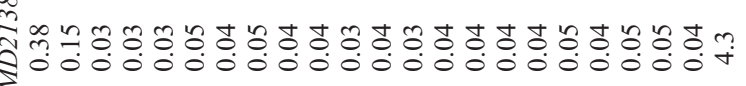

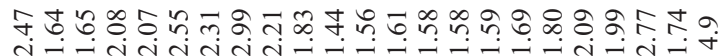

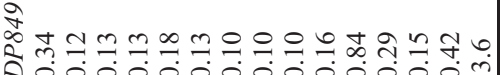

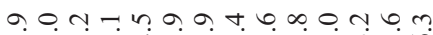

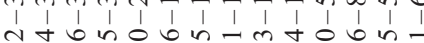

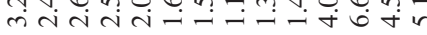

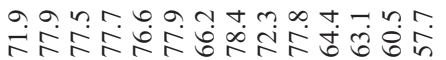

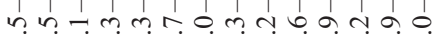

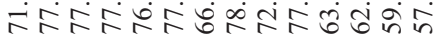

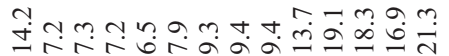

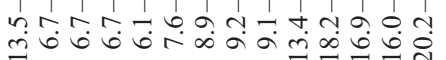

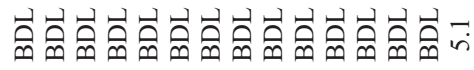

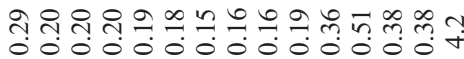

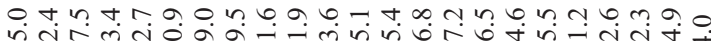

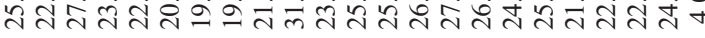

䑻

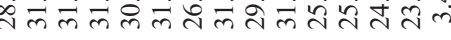

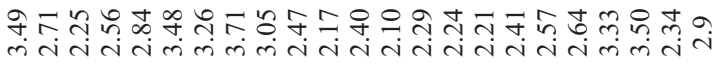

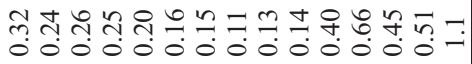

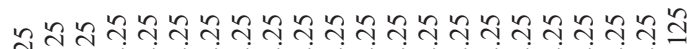

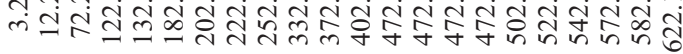

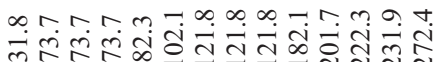

nn

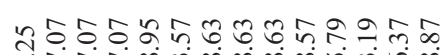

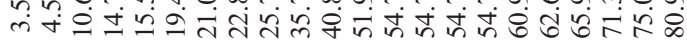
$\infty$ 드에

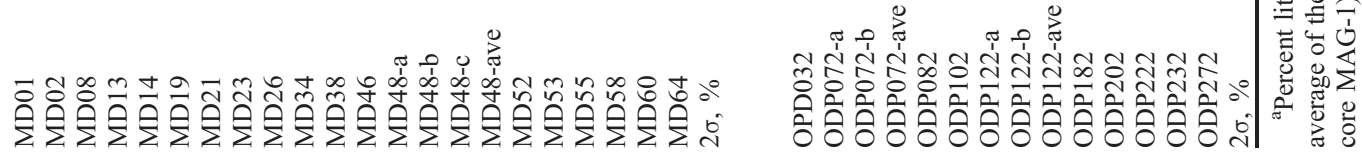


Table 2. Isotopic Data for Cores MD2138, BC36, and ODP849

\begin{tabular}{|c|c|c|c|c|c|c|c|}
\hline Sample & Age, ka & Depth, cm & $\left({ }^{238} \mathrm{U}\right), \mathrm{dpm} / \mathrm{g}$ & $\left({ }^{232} \mathrm{Th}\right), \mathrm{dpm} / \mathrm{g}$ & $\left({ }^{230} \mathrm{Th}\right)_{\mathrm{xs}, 0}, \mathrm{dpm} / \mathrm{g}$ & $\left({ }^{231} \mathrm{~Pa}\right)_{\mathrm{xs}, 0}, \mathrm{dpm} / \mathrm{g}$ & $\left({ }^{231} \mathrm{~Pa} /{ }^{230} \mathrm{Th}\right)_{\mathrm{xs}, 0}$ \\
\hline & & & & $M D 2138$ & & & \\
\hline MD01 & 3.5 & 3.25 & 0.42 & 0.28 & 3.84 & 0.49 & 0.129 \\
\hline MD02-a & 4.5 & 12.25 & 0.49 & 0.25 & 3.96 & 0.45 & 0.113 \\
\hline MD02-b & 4.5 & 12.25 & 0.44 & 0.23 & 4.12 & 0.49 & 0.120 \\
\hline MD03-1 & 5.7 & 22.25 & 0.31 & 0.18 & 3.84 & 0.48 & 0.125 \\
\hline MD03-2 & 5.7 & 22.25 & 0.31 & 0.18 & 3.84 & 0.48 & 0.126 \\
\hline MD04 & 6.8 & 32.25 & 0.36 & 0.18 & 2.98 & 0.49 & 0.166 \\
\hline MD06 & 8.8 & 52.25 & 0.42 & 0.20 & 3.69 & 0.55 & 0.149 \\
\hline MD08-b & 10.6 & 72.25 & 1.68 & 0.24 & 3.79 & 0.47 & 0.123 \\
\hline MD08-c1 & 10.6 & 72.25 & 1.68 & 0.23 & 3.75 & 0.44 & 0.119 \\
\hline MD08-c2 & 10.6 & 72.25 & 1.66 & 0.23 & 3.75 & 0.43 & 0.115 \\
\hline MD08-d1 & 10.6 & 72.25 & 1.64 & 0.23 & 3.66 & 0.43 & 0.119 \\
\hline MD08-d2 & 10.6 & 72.25 & 1.64 & 0.23 & 3.66 & 0.44 & 0.121 \\
\hline MD10 & 12.3 & 92.25 & 1.91 & 0.30 & 3.00 & 0.36 & 0.120 \\
\hline MD12 & 14.0 & 112.25 & 2.85 & 0.32 & 3.27 & 0.37 & 0.112 \\
\hline MD13-a & 14.7 & 122.25 & 2.31 & 0.35 & 3.02 & 0.22 & 0.073 \\
\hline MD13-b & 14.7 & 122.25 & 2.52 & 0.35 & 3.38 & 0.36 & 0.108 \\
\hline MD14 & 15.5 & 132.25 & 2.38 & 0.39 & 3.72 & 0.42 & 0.114 \\
\hline MD15 & 16.3 & 142.25 & 2.22 & 0.35 & 3.34 & 0.35 & 0.104 \\
\hline MD16 & 17.1 & 153.25 & 2.62 & 0.34 & 3.63 & 0.42 & 0.116 \\
\hline MD17 & 17.8 & 162.25 & 2.85 & 0.33 & 3.47 & 0.40 & 0.114 \\
\hline MD18 & 18.6 & 172.25 & 2.48 & 0.35 & 3.25 & 0.34 & 0.105 \\
\hline MD19 & 19.4 & 182.25 & 2.53 & 0.34 & 3.57 & 0.43 & 0.121 \\
\hline MD20-a & 20.2 & 192.25 & 2.72 & 0.35 & 3.74 & 0.40 & 0.106 \\
\hline MD20-b & 20.2 & 192.25 & 2.76 & 0.31 & 3.64 & 0.45 & 0.123 \\
\hline MD20-c & 20.2 & 192.25 & 2.72 & 0.31 & 3.81 & 0.47 & 0.123 \\
\hline MD20-d & 20.2 & 192.25 & 3.01 & 0.34 & 3.79 & 0.41 & 0.107 \\
\hline MD21 & 21.0 & 202.25 & 3.28 & 0.39 & 4.13 & 0.42 & 0.103 \\
\hline MD22 & 21.9 & 212.25 & 2.84 & 0.37 & 3.99 & 0.47 & 0.118 \\
\hline MD23 & 22.8 & 222.25 & 2.32 & 0.40 & 3.58 & 0.34 & 0.094 \\
\hline MD24 & 23.7 & 232.25 & 1.94 & 0.40 & 3.42 & 0.41 & 0.119 \\
\hline MD25 & 24.7 & 242.25 & 2.51 & 0.36 & 4.00 & 0.43 & 0.107 \\
\hline MD26 & 25.7 & 252.25 & 3.33 & 0.39 & 4.26 & 0.39 & 0.091 \\
\hline MD27 & 26.8 & 262.25 & 3.50 & 0.36 & 3.50 & 0.42 & 0.119 \\
\hline MD28 & 28.0 & 272.25 & 2.67 & 0.33 & 3.11 & 0.37 & 0.118 \\
\hline MD29 & 29.3 & 282.25 & 3.39 & 0.35 & 3.49 & 0.42 & 0.121 \\
\hline MD31-a & 32.0 & 303.25 & 3.70 & 0.33 & 3.36 & 0.41 & 0.124 \\
\hline MD31-b & 32.0 & 303.25 & 3.58 & 0.29 & 3.78 & 0.49 & 0.129 \\
\hline MD31-c & 32.0 & 303.25 & 3.57 & 0.29 & 3.80 & 0.51 & 0.133 \\
\hline MD34 & 35.7 & 332.25 & 2.80 & 0.25 & 3.36 & 0.46 & 0.137 \\
\hline MD38 & 40.8 & 372.25 & 2.76 & 0.26 & 3.36 & 0.45 & 0.135 \\
\hline MD38 & 40.8 & 372.25 & 2.76 & 0.26 & 3.36 & 0.45 & 0.135 \\
\hline MD45-a1 & 48.9 & 432.25 & 3.30 & 0.29 & 3.84 & 0.53 & 0.139 \\
\hline MD45-a2 & 48.9 & 432.25 & 3.30 & 0.29 & 3.84 & 0.53 & 0.137 \\
\hline MD45-b & 48.9 & 432.25 & 3.16 & 0.38 & 4.00 & 0.57 & 0.143 \\
\hline MD45-c1 & 48.9 & 432.25 & 3.20 & 0.21 & 4.04 & 0.55 & 0.135 \\
\hline MD45-c2 & 48.9 & 432.25 & 3.20 & 0.21 & 4.05 & 0.55 & 0.134 \\
\hline MD46 & 51.9 & 453.25 & 2.16 & 0.23 & 3.13 & 0.47 & 0.152 \\
\hline MD47 & 53.2 & 462.25 & 2.63 & 0.27 & 3.29 & 0.37 & 0.113 \\
\hline MD48 & 54.7 & 472.25 & 2.71 & 0.26 & 2.63 & 0.35 & 0.132 \\
\hline MD51 & 59.3 & 502.25 & 2.39 & 0.32 & 2.92 & 0.37 & 0.127 \\
\hline MD52 & 60.9 & 512.25 & 2.83 & 0.35 & 3.35 & 0.32 & 0.095 \\
\hline MD53 & 62.6 & 522.25 & 2.79 & 0.34 & 3.56 & 0.40 & 0.112 \\
\hline MD54 & 64.2 & 532.25 & 2.32 & 0.37 & 3.82 & 0.43 & 0.114 \\
\hline MD55 & 65.9 & 542.25 & 0.49 & 0.25 & 6.73 & 0.69 & 0.102 \\
\hline MD56 & 67.7 & 552.25 & 2.12 & 0.40 & 3.74 & 0.50 & 0.133 \\
\hline MD57-a & 69.4 & 562.25 & 2.31 & 0.34 & 4.66 & 0.58 & 0.125 \\
\hline MD57-b & 69.4 & 562.25 & 2.24 & 0.33 & 4.60 & 0.63 & 0.136 \\
\hline MD58 & 71.3 & 572.25 & 2.28 & 0.38 & 4.04 & 0.53 & 0.132 \\
\hline MD60 & 75.0 & 592.25 & 3.37 & 0.24 & 3.90 & 0.55 & 0.142 \\
\hline MD64-a & 80.9 & 622.125 & 2.10 & 0.26 & 2.98 & 0.41 & 0.138 \\
\hline \multirow[t]{2}{*}{ MD64-b } & 80.9 & 622.125 & 2.19 & 0.26 & 2.97 & 0.47 & 0.157 \\
\hline & & & & $B C 36$ & & & \\
\hline BC36\#1-1 & 0.4 & 1.5 & 0.19 & 0.11 & 5.15 & 0.48 & 0.092 \\
\hline BC $36 \# 1-2$ & 0.4 & 1.5 & 0.19 & 0.11 & 5.15 & 0.48 & 0.093 \\
\hline ВC $36 \# 2$ & 2.8 & 10.5 & 0.18 & 0.09 & 4.96 & 0.45 & 0.092 \\
\hline BC36\#3 & 6.8 & 21.0 & 0.16 & 0.08 & 4.49 & 0.40 & 0.090 \\
\hline ВC $36 \# 4$ & 11.1 & 28.5 & 0.14 & 0.10 & 4.17 & 0.39 & 0.093 \\
\hline
\end{tabular}


Table 2. (continued)

\begin{tabular}{|c|c|c|c|c|c|c|c|}
\hline Sample & Age, ka & Depth, cm & $\left({ }^{238} \mathrm{U}\right), \mathrm{dpm} / \mathrm{g}$ & $\left({ }^{232} \mathrm{Th}\right), \mathrm{dpm} / \mathrm{g}$ & $\left({ }^{230} \mathrm{Th}\right)_{\mathrm{xs}, 0}, \mathrm{dpm} / \mathrm{g}$ & $\left({ }^{231} \mathrm{~Pa}\right)_{\mathrm{xs}, 0}, \mathrm{dpm} / \mathrm{g}$ & $\left({ }^{231} \mathrm{~Pa} /{ }^{230} \mathrm{Th}\right)_{\mathrm{xs}, 0}$ \\
\hline & & & & ODP849 & & & \\
\hline ODP012 & 4.35 & 11.8 & 0.27 & 0.03 & 11.11 & 1.29 & 0.116 \\
\hline ODP032 & 8.25 & 31.8 & 0.19 & 0.03 & 8.95 & 1.06 & 0.119 \\
\hline ODP042 & 10.52 & 42.2 & 0.19 & 0.05 & 9.25 & 1.08 & 0.116 \\
\hline ODP052 & 12.53 & 51.8 & 0.17 & 0.06 & 9.96 & 1.10 & 0.110 \\
\hline ODP062 & 14.56 & 61.7 & 0.13 & 0.05 & 10.52 & 1.02 & 0.097 \\
\hline ODP072 & 17.07 & 73.7 & 0.12 & 0.07 & 9.91 & 0.91 & 0.092 \\
\hline ODP082 & 18.95 & 82.3 & 0.12 & 0.08 & 11.10 & 0.99 & 0.089 \\
\hline ODP102 & 23.57 & 102.1 & 0.12 & 0.06 & 9.00 & 0.86 & 0.095 \\
\hline ODP112 & 26.04 & 112.1 & 0.11 & 0.05 & 8.50 & 0.71 & 0.084 \\
\hline ODP122 & 28.63 & 121.8 & 0.15 & 0.04 & 7.91 & 0.79 & 0.100 \\
\hline ODP142 & 34.36 & 141.6 & 0.12 & 0.05 & 8.31 & 0.89 & 0.107 \\
\hline ODP162-a & 41.07 & 162.1 & 0.12 & 0.05 & 9.07 & 0.92 & 0.101 \\
\hline ODP162-b & 41.07 & 162.1 & 0.12 & 0.03 & 9.05 & 0.89 & 0.098 \\
\hline ODP162-c & 41.07 & 162.1 & 0.12 & 0.03 & 8.93 & 0.91 & 0.102 \\
\hline ODP182 & 48.57 & 182.1 & 0.12 & 0.05 & 7.55 & 0.84 & 0.111 \\
\hline ODP202 & 55.79 & 201.7 & 0.16 & 0.10 & 14.53 & 1.28 & 0.088 \\
\hline ODP222 & 63.19 & 222.3 & 0.18 & 0.14 & 21.72 & 1.86 & 0.086 \\
\hline ODP232 & 66.37 & 231.9 & 0.14 & 0.12 & 20.07 & 1.84 & 0.092 \\
\hline ODP252 & 72.59 & 251.9 & 0.12 & 0.06 & 13.40 & 1.45 & 0.108 \\
\hline ODP 272 & 78.87 & 272.4 & 0.16 & 0.09 & 18.75 & 1.72 & 0.092 \\
\hline ODP292 & 85.36 & 291.8 & 0.13 & 0.10 & 20.39 & 1.99 & 0.098 \\
\hline
\end{tabular}

${ }^{\mathrm{a}}$ Full replicates are indicated by a dash followed by a letter after the name of the sample. Replicate analyses are indicated by a dash followed by a number after the name of the sample. Parentheses denote activity.

Thunell [1997] and two bulk sediment ${ }^{14} \mathrm{C}$ ages [Broecker et al., 1999].

\subsection{Analytical Procedures}

\subsubsection{Elemental analyses}

[18] The concentrations (wt \%) of $\mathrm{Al}, \mathrm{Ca}, \mathrm{Fe}, \mathrm{Mn}, \mathrm{Si}$, and Ti were measured in 19 samples of MD2138 and 10 samples of ODP849 (Table 1). Analyses were performed by inductively coupled plasma optical emission spectrometry (ICP-OES, Jobin Yvon JY38VHR). Accuracy was within $3 \%$ as determined by repetitive measurements of a standard (USGC marine sediment MAG-1). Precisions are reported in Table 1. The carbonate, opal and lithogenic content of the sediments were estimated by normative calculations assuming that all the $\mathrm{Al}$ is associated with the terrigenous fraction (see section 4.1) and using a mean detrital material chemical composition to estimate the terrigenous contribution for the other elements (i), according to:

$$
(\mathrm{i})_{\text {biogenic }}=(\mathrm{i})_{\text {total }}-=\left[(\mathrm{i} / \mathrm{Al})_{\mathrm{j}}(\mathrm{Al})_{\text {total }}\right] \text {, }
$$

where $\mathrm{j}$ is bulk continental crust (CC), upper continental crust (UPCC), terrigenous post-Archean Australian terrigenous shales (PAAS) as defined by Taylor and McLennan [1985] or mafic rocks from the Manus basin (MRMB) as given in the text (see section 4.1).

\subsubsection{The ${ }^{231} \mathrm{~Pa}$ and ${ }^{230} \mathrm{Th}$ Analyses}

[19] ${ }^{231} \mathrm{~Pa}$ and ${ }^{230} \mathrm{Th}$ (Table 2) were measured by isotopic dilution using ${ }^{233} \mathrm{~Pa}$ and ${ }^{229} \mathrm{Th}$ spike, respectively, on a single collector, sector field inductively coupled plasma mass spectrometer (SF-ICP-MS), following the procedures described in the work of Choi et al. [2001], Pichat [2001] and S. Pichat et al. (manuscript in preparation, 2004). Briefly, the sediment samples were spiked and equilibrated with ${ }^{233} \mathrm{~Pa}$ and ${ }^{229} \mathrm{Th}$ prior to total dissolution in $\mathrm{HNO}_{3}, \mathrm{HF}$ and $\mathrm{HClO}_{4}$. An aliquot, representing less than $1 \mathrm{wt} \%$, of the resulting solution was analyzed directly for ${ }^{238} \mathrm{U}$ and ${ }^{232} \mathrm{Th}$ by isotope dilution using ${ }^{236} \mathrm{U}$ and ${ }^{229} \mathrm{Th}$ spikes. The remaining solution was used for ${ }^{231} \mathrm{~Pa}$ and ${ }^{230} \mathrm{Th}$ separation by ion-exchange chromatography, slightly modified from Fleer and Bacon [1991] and subsequently analyzed by SF-ICP-MS (Finnigan, Element) in low resolution mode. The instrumental mass fractionation was evaluated by bracketing each sample measurement with analyses of an uranium standard (National Bureau of Standards NBS 960) (S. Pichat et al., manuscript in preparation, 2004). The signal was corrected from the contributions of the instrumental background, dark noise, blanks linked to the chemical procedure, and blanks linked to spike addition (S. Pichat et al., manuscript in preparation, 2004). The sum of these contributions was always $<0.5 \%$, and usually $<0.1 \%$, of the signal. The internal precision, i.e., the calculated uncertainty based on two times the standard error $(2 \sigma)$ propagated from the ${ }^{231} \mathrm{~Pa},{ }^{233} \mathrm{~Pa},{ }^{230} \mathrm{Th}$ and ${ }^{229} \mathrm{Th}$ measurements, on the $\left({ }^{231} \mathrm{~Pa} /{ }^{230} \mathrm{Th}\right)_{\mathrm{xs}, 0}$ ratios was usually better than $1.5 \%$. Reproducibility for full replicate analyses (dissolution, chromatographic separation and spectrometry) was usually better than $5 \%(2 \sigma)$ on the $\left({ }^{231} \mathrm{~Pa} /{ }^{230} \mathrm{Th}\right)_{\mathrm{xs}, 0}$ ratio. Initial excess activities were obtained after corrections for (1) the detrital ${ }^{230} \mathrm{Th}$ or ${ }^{231} \mathrm{~Pa}$ contribution, estimated from the ${ }^{232} \mathrm{Th}$ content of the sediment and using the average $\left({ }^{238} \mathrm{U} /{ }^{232} \mathrm{Th}\right)$ activity ratio of the lithogenic fraction of the marine sediments: $0.8 \pm 0.2$ [Anderson et al., 1990] for ODP849 and BC36, $1.0 \pm 0.3$ for MD2138 (see section 4.1), (2) the decay since the time of sediment deposition estimated from the age model of each core, and (3) the postdepositional 

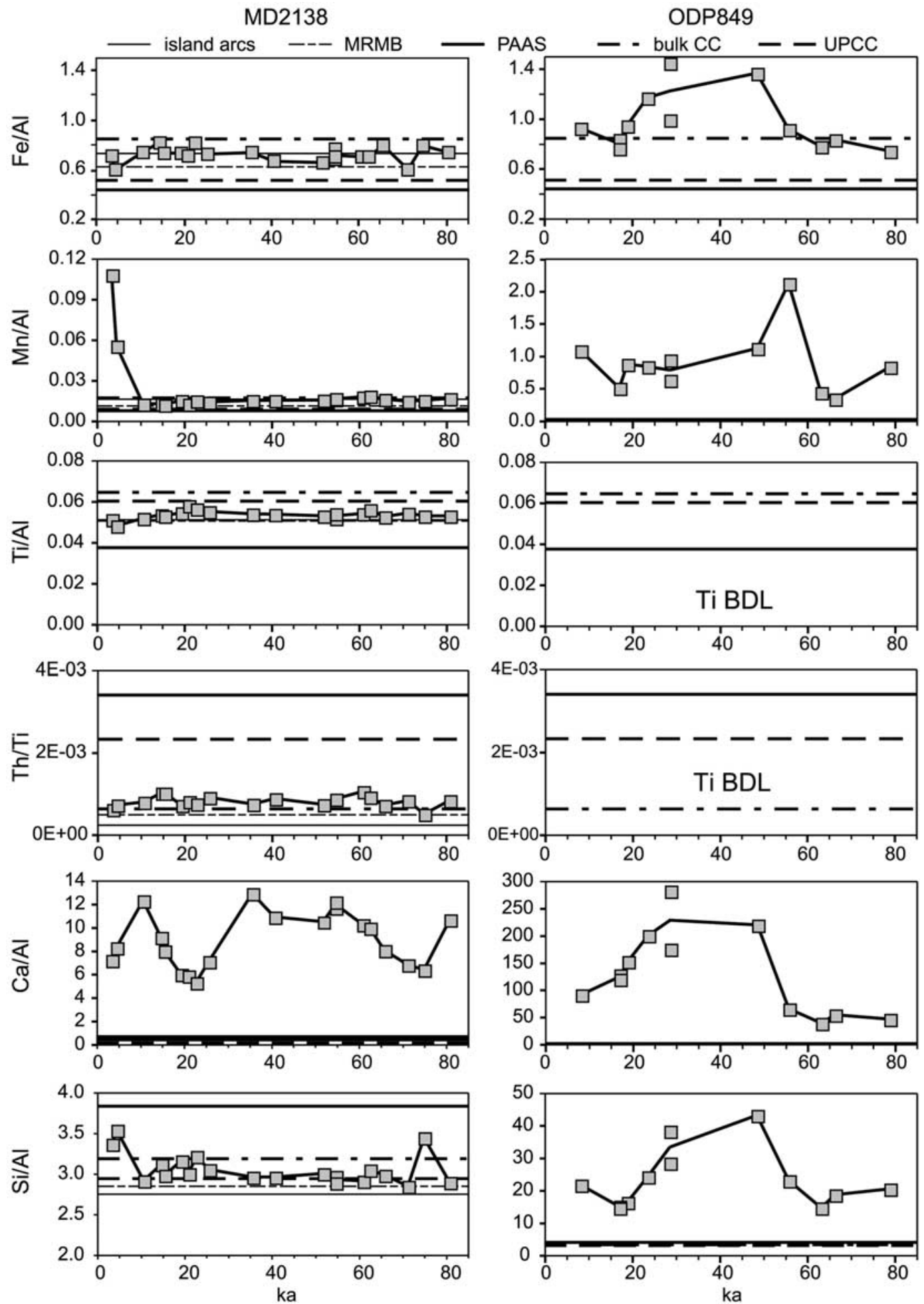

Figure 2. Elemental ratios measured in cores (left) MD2138 and (right) ODP849. The horizontal lines represent: terrigenous post-Archean Australian terrigenous shales (PAAS, thick dashed line), upper continental crust (UPCC, thick continuous line), bulk continental crust (CC, thick dot-dashed line) [Taylor and McLennan, 1985], mafic rocks from the Manus basin (MRMB, thin continuous line, data compiled from Stracke and Hegner [1998] and Gill et al. [1993], see section 4.1 for explanations) and island arcs (thin dashed line) [Taylor and McLennan, 1995]. BDL, below detection limits. 

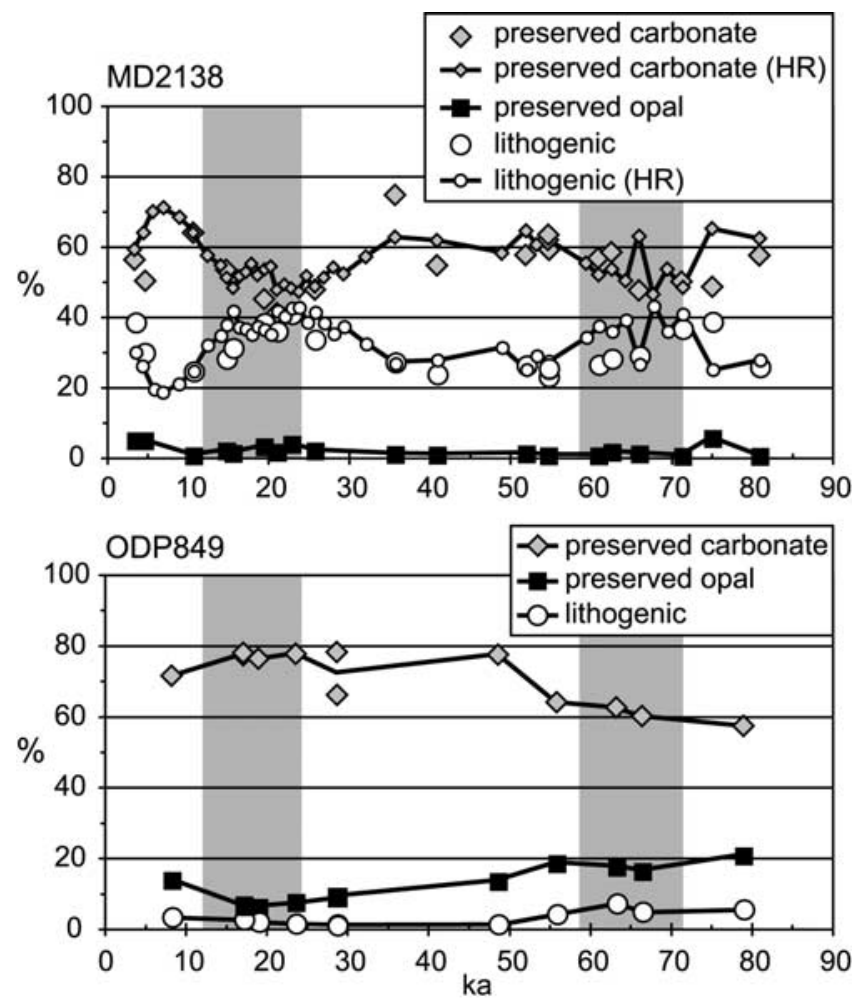

Figure 3. Sediment composition deduced from elemental ratios (large symbols). The smaller connected symbols for MD2138 represent estimates derived from our high resolution (HR) ${ }^{232} \mathrm{Th}$ measurements (see text for explanations). For MD2138, reported preserved opal represents the maximum values, i.e., using a pure MRMB end-member (MRMB: mafic rocks from the Manus basin, see section 4.1 for explanations) for the lithogenic fraction of the sediment. Glacial periods (isotopic stages 2 and 4 ) are shown in light gray [Martinson et al., 1987].

ingrowth of ${ }^{230} \mathrm{Th}$ or ${ }^{231} \mathrm{~Pa}$ when authigenic uranium was present.

\section{Results}

\subsection{Elemental Composition of Sediments From Sites MD2138 and ODP849}

[20] The elemental compositions of MD2138 and ODP849 (Table 1) show a clear contrast between the two cores. Given the location of MD2138, the lithogenic fraction of the sediment is likely to be dominated by mafic rocks. The ${ }^{232} \mathrm{Th} / \mathrm{Ti}$ and $\mathrm{Ti} / \mathrm{Al}$ ratios were used to estimate the chemical composition of the lithogenic components of MD2138 sediment. The ${ }^{232} \mathrm{Th} / \mathrm{Ti}$ ratios of MD2138 lie between two end-members: a low ${ }^{232} \mathrm{Th} / \mathrm{Ti}$ ratio represented by mafic rocks, either MRMB (a compilation of mafic rocks data from the Manus basin) or island arcs [Taylor and McLennan, 1995], and a high ${ }^{232} \mathrm{Th} / \mathrm{Ti}$ ratio represented either by the terrigenous PAAS (post-Archean Australian terrigenous shales) or the UPCC (upper continental crust) (Figure 2). The Ti/Al values of MD2138 (Figure 2) also lie between those of the mafic rocks and the terrigenous PAAS or the UPCC. However, the ${ }^{232} \mathrm{Th} / \mathrm{Ti}$ panel shows that if the UPCC contributes to the detrital fraction of MD2138 sediments, it is likely to be insignificant. The elemental ratios of MRMB and island arcs are very similar (Figure 2). We have chosen to use our compiled mafic rocks values from the Manus basin (MRMB) [Gill et al., 1993; Stracke and Hegner, 1998] to make the normative calculations rather the average island arcs values of Taylor and McLennan [1995] in order to match the geographical settings of MD2138. We have therefore chosen MRMB and PAAS as end-members for the detrital fraction of the MD2138 sediment. In MD2138, $\mathrm{Ca} / \mathrm{Al}$ is much higher than expected from MRMB or PAAS while $\mathrm{Si} / \mathrm{Al}$ is close to lithogenic material values. These elemental compositions clearly indicates that the sediment accumulated at the western Pacific site (MD2138) is dominated by biogenic carbonate and lithogenic material. Because of its high concentration, the carbonate content can be accurately estimated by normative calculations (equation (4)). There is no difference in using Ti instead of $\mathrm{Al}$ as the normative element in MD2138 which shows that there is probably no, or very little, $\mathrm{Al}_{\mathrm{xs}}$ [Murray et al., 1993]. Thus we choose to use $\mathrm{Al}$ rather than $\mathrm{Ti}$ because concentrations for the latter are low in MD2138 and below detection limits for ODP849 (Table 1). Calculations using CC, UPCC, PAAS or MRMB show an overall variation of less than $6 \mathrm{wt} \%$ in the carbonate estimate and less than $4 \mathrm{wt} \%$ in the lithogenic estimate. The range of values given in Table 1 reflects the use of MRMB or PAAS as lithogenic component for the normative calculations. Percent biogenic Si is estimated by normative calculations using a lithogenic $\mathrm{Si} / \mathrm{Al}=2.75$ for the MRMB and 2.93 for the PAAS [Taylor and McLennan, 1985]. A factor of 2.4 is then used to convert percent biogenic Si to percent biogenic opal [Mortlock and Froelich, 1989]. Calculations based on the PAAS show no preserved opal except $\sim 3.5 \mathrm{wt} \%$ in the top $15 \mathrm{~cm}$ of the core. An average value of $2 \mathrm{wt} \%$ preserved opal is calculated when using the MRMB endmember. In this latter case, the upper $15 \mathrm{~cm}$ of MD2138 show a preserved opal of $\sim 5 \mathrm{wt} \%$ (Table 1). Overall, given the uncertainties of the measurements, the preserved opal fraction in MD2138 is likely to be insignificant. From the analyses of the 19 MD2138 samples, we can deduce the mean ${ }^{232} \mathrm{Th}$ concentration of the lithogenic sediment deposited at this site $(3.8 \pm 0.6 \mathrm{ppm})$, and use the ${ }^{232} \mathrm{Th}$ concentrations measured at higher resolution (Table 2) to derive higher resolution profiles of percent lithogenic and percent carbonate (Figure 3). From the mean ${ }^{232} \mathrm{Th}$ concentration, we can also calculate the relative contribution of the two end-members, MRMB $\left({ }^{232} \mathrm{Th} \sim 1.15 \mathrm{ppm}\right)$ and PAAS $\left({ }^{232} \mathrm{Th} \sim 14.6 \mathrm{ppm}\right)$, to the lithogenic fraction assuming a binary mixing. We found that the MRMB contributes to $80 \pm$ $5 \%$ of the lithogenic fraction of the sediment (Table 3 ). This result allows us to calculate an average ${ }^{238} \mathrm{U}$ over ${ }^{232} \mathrm{Th}$ activity ratio for the lithogenic fraction of MD2138: $\left({ }^{238} \mathrm{U} /{ }^{232} \mathrm{Th}\right)_{\text {litho }}=1.0 \pm 0.1$ (Table 3). However, we choose to use a wider range of $\left({ }^{238} \mathrm{U} /{ }^{232} \mathrm{Th}\right)_{\text {litho }}=1.0 \pm 0.3$ to take into account the uncertainties in the estimation of the relative contributions of the two end-members.

[21] In contrast to MD2138, elemental ratios at the ODP849 site (Table 1; Figure 2) reveal the presence of 
Table 3. Estimation of the $\left({ }^{238} \mathrm{U} /{ }^{232} \mathrm{Th}\right)$ Activity Ratio of the Lithogenic Fraction of MD $2138^{\mathrm{a}}$

\begin{tabular}{lccccc}
\hline & $\mathrm{Th}, \mathrm{ppm}$ & $\mathrm{U}, \mathrm{ppm}$ & $(\mathrm{Th}), \mathrm{dpm} / \mathrm{g}$ & $(\mathrm{U}), \mathrm{dpm} / \mathrm{g}$ & $\left({ }^{238} \mathrm{U} /{ }^{232} \mathrm{Th}\right)$ \\
\hline MRMB & 1.15 & 0.82 & 0.28 & 0.61 & 2.18 \\
PAAS & 14.6 & 3.1 & 3.55 & 2.31 & 0.65 \\
Island arcs & 2.5 & 1.0 & 0.61 & 0.75 & 1.23 \\
75\% MRMB + 25\% PAAS & 4.5 & 1.4 & 1.10 & 0.95 & 0.94 \\
80\% MRMB + 20\% PAAS & 3.8 & 1.3 & 0.93 & 0.87 & 1.02 \\
85\% MRMB + 15\% PAAS & 3.2 & 1.1 & 0.77 & 0.87 \\
\hline
\end{tabular}

${ }^{\mathrm{a}}$ MRMB, mafic rocks from the Manus Basin (see text); PAAS, post-Archean Australian terrigenous shales [Taylor and McLennan, 1985]. The average island arcs values [Taylor and McLennan, 1995] are given for comparison. Parentheses denote activity.

significant biogenic opal burial in addition to carbonate. Both $\mathrm{Al}$ and ${ }^{232} \mathrm{Th}$ concentrations indicate that the lithogenic content is about ten-fold lower than at the western site, and account for only a few percents of the sediment mass (Table 1). Ti concentrations are below detection limits. Under these circumstances, the dominant carbonate phase can be accurately determined from percent $\mathrm{Ca}$ after a minor correction for lithogenic contribution, using equation (4) (Figure 3). The percent preserved opal is estimated as for MD2138 (Figure 3). The small lithogenic component is best quantified from $\mathrm{Al}$ concentrations (Figure 3). The range of values given in Table 1 reflects the use of PAAS, UPCC or $\mathrm{CC}$ as lithogenic component. Using PAAS, UPCC or CC for the normative calculations results in variations lower than $0.6 \%$ for the different fractions.

\subsection{Contrasting Redox States Between Core MD2138 and ODP849}

[22] In the western Pacific core, $\mathrm{Mn} / \mathrm{Al}$ lie between the MRMB and the PAAS values, except for the core top, showing evidence of Mn diagenetic reductive remobilization (Figure 2). MD2138 sediment becomes sufficiently reducing between $12 \mathrm{~cm}$ and $72 \mathrm{~cm}$ depth to reduce $\mathrm{MnO}_{2}$. In contrast, $\mathrm{Mn} / \mathrm{Al}$ ratio remains very high compared to the CC, UPCC or PAAS values over the entire length of ODP849, indicating that the sediment deposited at this site during the last 80 ka remained oxic. $\mathrm{MnO}_{2}$ concentrations (Table 1) were estimated by normative calculations using PAAS or MRMB Mn/Al values for MD2138 and CC, UPCC or PAAS [Taylor and McLennan, 1985] Mn/Al values for ODP849. For the eastern Pacific, normative calculations using the Mn/Al ratios of CC, UPCC or PAAS give the same $\mathrm{MnO}_{2}$ concentrations.

[23] The contrast in redox conditions between the two cores is confirmed by their respective authigenic $U$ concentrations (Figure 4). Uranium diffuses from bottom water and precipitates in suboxic and anoxic sediment pore waters [e.g., Barnes and Cochran, 1990; Mangini et al., 2001]. This authigenic fraction of sedimentary $\mathrm{U}$ can be estimated by normative calculations using the average $\left({ }^{238} \mathrm{U} /{ }^{232} \mathrm{Th}\right)$ activity ratio of the lithogenic fraction of the marine sediments $(0.8 \pm 0.2$ [Anderson et al., 1990] for ODP849 and $\mathrm{BC} 36 ; 1.0 \pm 0.3$ for MD2138):

$$
\begin{aligned}
\left({ }^{238} \mathrm{U}\right)_{\text {authigenic }}= & \left({ }^{238} \mathrm{U}\right)_{\text {total }}-\left[\left({ }^{238} \mathrm{U} /{ }^{232} \mathrm{Th}\right)_{\text {litho }}\right. \\
& \left.\cdot\left({ }^{232} \mathrm{Th}\right)_{\text {total }}\right] .
\end{aligned}
$$

[24] The results clearly confirm reducing conditions, i.e., high authigenic $U$ activity, below $60 \mathrm{~cm}$ depth in core MD2138. However, very little or no authigenic U accumulates in ODP849.

\subsection{Variations in $\left({ }^{231} \mathrm{~Pa} /{ }^{230} \mathrm{Th}\right)_{\mathrm{xs}, 0}$}

[25] The short Ontong Java Plateau core (BC36) records a nearly constant $\left({ }^{231} \mathrm{~Pa} /{ }^{230} \mathrm{Th}\right)_{\mathrm{xs}, 0}$ over the entire Holocene that is very similar to the production rate ratio (Figure 5). However, the two longer records from the western (MD2138) and eastern (ODP849) equatorial Pacific display systematic and similar variations in $\left({ }^{231} \mathrm{~Pa} /{ }^{230} \mathrm{Th}\right)_{\mathrm{xs}, 0}$, with minima close to the production rate ratio during the colder isotopic stages 2 (IS2) and 4 (IS4), and maxima during the warmer isotopic stages 1
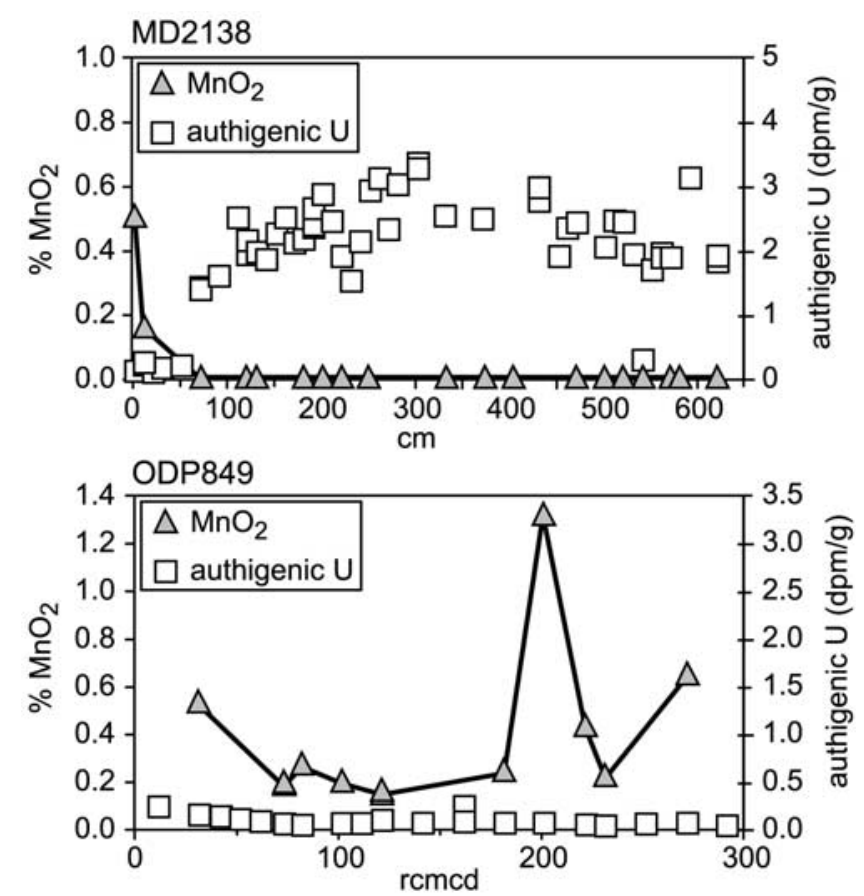

Figure 4. $\mathrm{MnO}_{2}$ and authigenic $\mathrm{U}$ concentrations in MD2138 and ODP849 calculated by normalization to Al for $\mathrm{MnO}_{2}$ and to ${ }^{232} \mathrm{Th}$ for U. rcmcd: revised centimeters composite depth [Mix et al., 1995]. 

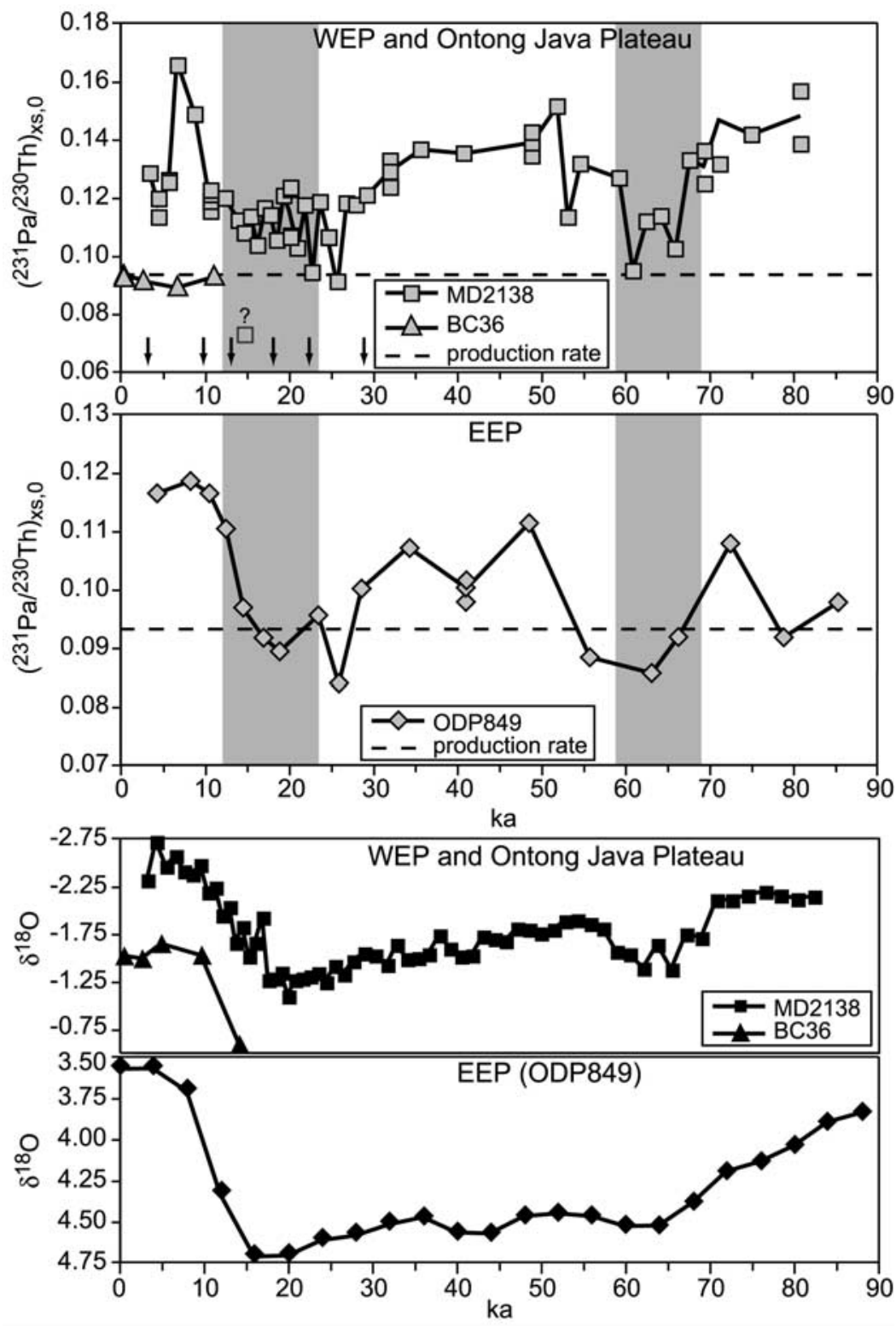

Figure 5. $\left({ }^{231} \mathrm{~Pa} /{ }^{230} \mathrm{Th}\right)_{\mathrm{xs}, 0}$ and $\delta^{18} \mathrm{O}$ in MD2138, BC36 and ODP849. Glacial periods (isotopic stages 2 and 4) are shown in light gray [Martinson et al., 1987]. See section 3.2 for information about the $\delta^{18} \mathrm{O}$ records. The vertical arrows in the upper panel represent the depth of the ${ }^{14} \mathrm{C}$ ages that were used to calculate the MD2138 age model (T. de Garidel-Thoron, manuscript in preparation, 2004). EEP, eastern equatorial Pacific; WEP, western equatorial Pacific.

(IS1), 3 (IS3) and 5a (IS5a) (Figure 5). $\left({ }^{231} \mathrm{~Pa} /{ }^{230} \mathrm{Th}\right)_{\mathrm{xs}, 0}$ is consistently higher at the western site.

\subsection{The ${ }^{230}$ Th-Normalized Fluxes}

[26] The total preserved rain rates are higher in the WEP $\left(\sim 1.4 \mathrm{~g} / \mathrm{cm}^{2} / \mathrm{ka}\right)$, reflecting primarily higher fluxes of lithogenic material (Figure 6). Preserved carbonate rain rates in MD2138 reach maximum values during IS1, IS3 and IS5a, coincident to maxima in $\left({ }^{231} \mathrm{~Pa} /{ }^{230} \mathrm{Th}\right)_{\mathrm{xs}, 0}$ (Figure 5). In the EEP (ODP849), total preserved rain rates increase sharply around $55 \mathrm{ka}$ from $\sim 0.5 \mathrm{~g} / \mathrm{cm}^{2} / \mathrm{ka}$ to $\sim 1.1 \mathrm{~g} / \mathrm{cm}^{2} / \mathrm{ka}$. This variation is mainly due to a drastic change in preserved carbonate rain rates, which may reflect either a change in carbonate production in the overlying water or a change in carbonate preservation on the seafloor. Our ODP849 preserved opal fluxes record (Figure 6) also suggests two minima during IS2 and IS4, coincident with the two minima in $\left({ }^{231} \mathrm{~Pa} /{ }^{230} \mathrm{Th}\right)_{\mathrm{xs}, 0}$.

\subsection{Syndepositional Sediment Redistribution $(\psi)$}

[27] The sediment focusing factor $(\psi)$ has been calculated using equation (3), averaging the dry bulk density and $\left({ }^{230} \mathrm{Th}_{\mathrm{xs}, 0}\right)$ over the four climatic stages delineated by the $\delta^{18} \mathrm{O}$ profiles (Table 4; Figure 7). Both cores show evidence for sediment focusing $(\psi>1)$. $\psi$ increases with time from $\sim 2$ to $\sim 4$ in MD2138 with slightly higher values during IS2 

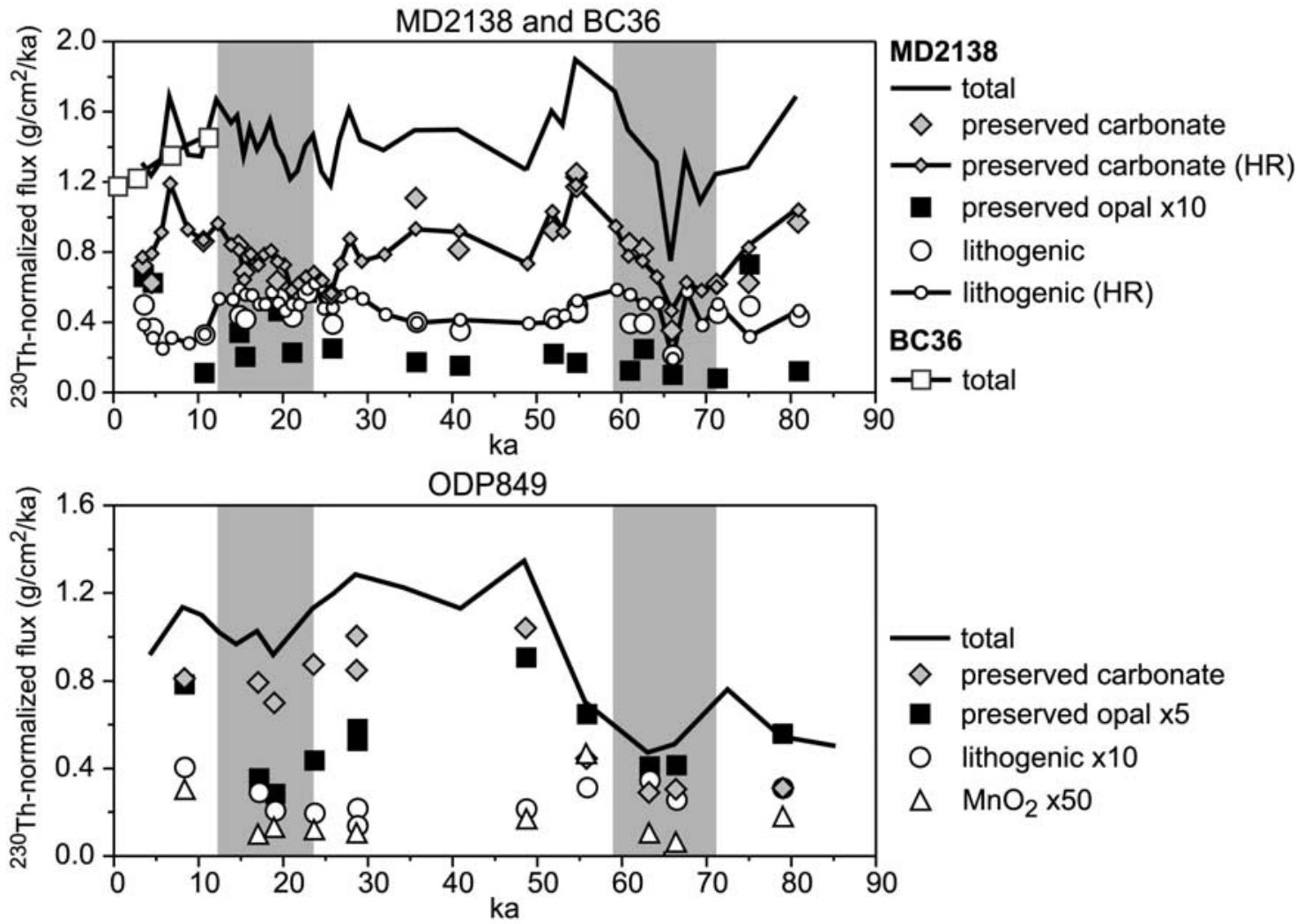

Figure 6. ${ }^{230}$ Th-normalized fluxes (or preserved vertical rain rates) in cores MD2138 and ODP849. Large symbols represent fluxes deduced from elemental ratios. The smaller high resolution (HR) connected symbols for MD2138 represent estimates derived from ${ }^{232} \mathrm{Th}$ (see text for explanations). Glacial periods (isotopic stages 2 and 4) are shown in light gray [Martinson et al., 1987].

than during the Holocene. At ODP site $849, \psi$ is clearly higher during IS2 and IS4.

\section{Discussion}

\subsection{Authigenic U Accumulations in MD2138}

[28] A surprising aspect of core MD2138 is its reducing conditions below $60 \mathrm{~cm}$ depth that enabled the dissolution and remobilization of $\mathrm{MnO}_{2}$ and the precipitation of authigenic $U$ (Figure 4). We have estimated the depth $\left(Z_{U}\right)$ at which the sediment had to become sufficiently reducing to precipitate $\mathrm{U}$, assuming that pore water $\mathrm{U}$ concentration approaches zero at this depth [e.g., François et al., 1993]:

$$
\mathrm{Z}_{\mathrm{U}}=\mathrm{D}_{\mathrm{U}}[\mathrm{U}]_{\mathrm{sw}} /\left(\mathrm{SR} \rho^{\text {auth }}[\mathrm{U}]_{\mathrm{sed}}\right)
$$

where $\mathrm{D}_{\mathrm{U}}$ is the pore water diffusion coefficient for $\mathrm{U}, 3 \times$ $10^{-6} \mathrm{~cm}^{2} / \mathrm{s}$ [Klinkhammer and Palmer, 1991]; [U] $]_{\mathrm{sw}}$ is the concentration of $U$ in seawater, $1.3 \times 10^{-11} \mathrm{~mol} / \mathrm{cm}^{3}$; $\mathrm{SR}$ is the sedimentation rate, $\mathrm{cm} / \mathrm{s} ; \rho$ is dry bulk density, $\mathrm{g} / \mathrm{cm}^{3}$; and ${ }^{\text {auth }}[\mathrm{U}]_{\text {sed }}$ is the authigenic $\mathrm{U}$ concentration in sediment, $\mathrm{mol} / \mathrm{g}$.

[29] Applying equation (6) to the authigenic U profile in MD2138 gives $Z_{U} \sim 20-35 \mathrm{~cm}$. Using the $D_{U}$ value of Mangini et al. [2001] $\left(\mathrm{D}_{\mathrm{U}}=1.09 \times 10^{-6} \mathrm{~cm}^{2} / \mathrm{s}\right)$ would give a slightly shallower depth $Z_{U} \sim 6-12 \mathrm{~cm}$. Authigenic $U$ ceased to accumulate above $70 \mathrm{~cm}$ depth, i.e., around $10 \mathrm{ka}$ (Figure 4), i.e., soon after the last deglaciation. Reducing conditions in sediments result either from low oxygen concentration in bottom water or from high flux of labile organic matter to the sediment. MD2138 is located in a region that is not characterized by oxygen-deficient intermediate or deep waters at Present [Deuser, 1975]. Low oxygen concentrations in bottom waters of the WEP would imply a dramatic slowdown of intermediate and deep water circulation in this area. Studies have shown that Pacific intermediate and deep

Table 4. Sediment Focusing in Core MD2138 and ODP849

\begin{tabular}{|c|c|c|c|c|}
\hline $\begin{array}{l}\text { Isotopic } \\
\text { Stage } \\
\end{array}$ & $\begin{array}{l}\text { Sedimentation } \\
\text { Rate, } \mathrm{cm} / \mathrm{kyr}\end{array}$ & $\begin{array}{c}\text { Average } \\
\text { Carbonate, \% }\end{array}$ & $\begin{array}{l}\text { Average DBD, } \\
\mathrm{g} / \mathrm{cm}^{3}\end{array}$ & $\begin{array}{l}\text { Focusing } \\
\text { Factor, } \psi\end{array}$ \\
\hline \multicolumn{5}{|c|}{$M D 2138$} \\
\hline Holocene & 9.4 & 62 & 0.52 & 3.6 \\
\hline IS2 & 12.3 & 52 & 0.44 & 4.1 \\
\hline IS3 & 8.1 & 64 & 0.55 & 3.7 \\
\hline IS4 & 6.0 & 59 & 0.50 & 3.0 \\
\hline IS5a & 5.3 & 57 & 0.48 & 2.0 \\
\hline \multicolumn{5}{|c|}{ ODP849 } \\
\hline Holocene & 3.5 & 72 & 0.62 & 2.1 \\
\hline IS2 & 4.3 & 77 & 0.69 & 3.0 \\
\hline IS3 & 4.0 & 71 & 0.62 & 1.8 \\
\hline IS4 & 3.5 & 61 & 0.52 & 2.7 \\
\hline
\end{tabular}

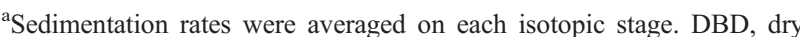
bulk density. 


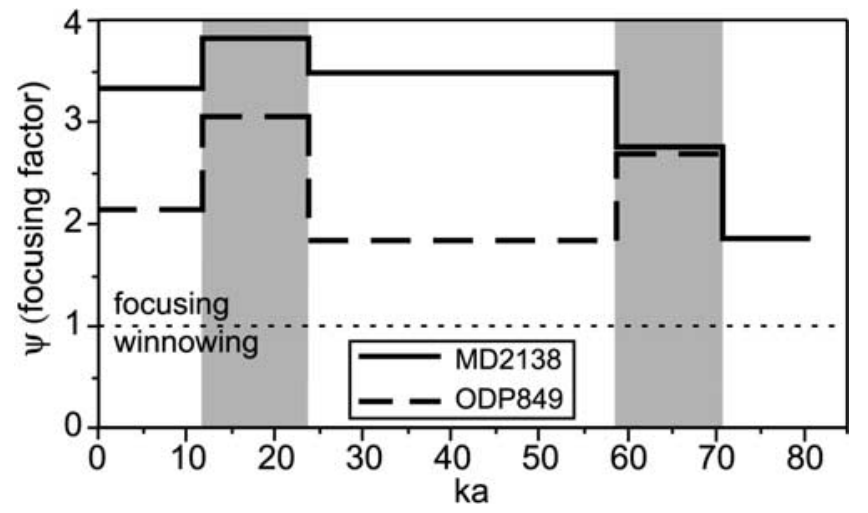

Figure 7. Estimates of sediment focusing $(\psi)$ as a result of syndepositional sediment redistribution by bottom currents (see text for explanations). The horizontal dashed line represents the limit between focusing $(\psi>1)$ and winnowing $(\psi<1)$. Glacial periods (isotopic stages 2 and 4) are shown in light gray [Martinson et al., 1987].

water circulation has either remained similar to the Present circulation or had an additional north Pacific component during the LGM [Matsumoto and Lynch-Stieglitz, 1999; Matsumoto et al., 2002]. It is therefore unlikely that bottom waters overlying the site of MD2138 ever had very low concentrations of oxygen resulting from a change in deep water circulation. Hence high flux of labile organic matter appears to be the most likely explanation for the reducing conditions in MD2138. The timing of the change of the reducing conditions in MD2138 suggests that this event is associated with the last deglaciation. Core MD2138 was collected on the continental slope of Manus Island. Sediment accumulation rates are relatively high, particularly during the last $24 \mathrm{ka}(\sim 11 \mathrm{~cm} / \mathrm{ka}$; Table 4$) .{ }^{230} \mathrm{Th}$ accumulation indicates significant focusing of sediment (Figure 7). Low sea level stand results in greater input of lithogenic material to the deep sea [e.g., François and Bacon, 1991], and we do find a significant $(40-50 \%)$ decrease of the lithogenic flux during the last deglaciation (Figure 6). Given MD2138 location, the laterally transported sediments are likely to reach the coring site by downslope transport from shallower depths, supplying enough labile organic matter to induce reducing conditions in core MD2138. Accumulation of authigenic $U$ in sediments as a result of sediment focusing has also been observed in other oceanic regions [e.g., François et al., 1993]. However, there are no clear changes in focusing factor during deglaciation, which could readily explain the redox transition (Figure 7). At this stage, we can only speculate that the amount of organic matter associated with the sediment transported downslope could have been higher before the last deglaciation. Further studies will be needed to solve this problem. In particular, it would be interesting to check whether the redox conditions have changed at the last deglaciation over the entire basin where MD2138 is located or only locally.

\section{2. $\left({ }^{231} \mathrm{~Pa} /{ }^{230} \mathrm{Th}\right)_{\mathrm{xs}}$ in Surface Sediment}

[30] In the Pacific Ocean, the residence time of deep water ( $\sim 600$ years) is much longer than the lateral diffusive mixing time ( $\sim 100$ years [Anderson et al., 1990]), thus allowing a full expression of boundary scavenging and a greater sensitivity of $\left({ }^{231} \mathrm{~Pa} /{ }^{230} \mathrm{Th}\right)_{\mathrm{xs}, 0}$ to particle flux [Yu et al., 2001]. In order to further document the extent of boundary scavenging in the Pacific ocean, we have compared $\left({ }^{231} \mathrm{~Pa} /{ }^{230} \mathrm{Th}\right)_{\mathrm{xs}}$ in surface sediment with estimates of export production. The latter was obtained from ocean color measurements by satellite and a temperature-dependent ecosystem model [Laws et al., 2000].

[31] In the EEP, we find a significant linear correlation $\left(\mathrm{R}^{2}=0.69\right)$ between $\left({ }^{231} \mathrm{~Pa} /{ }^{230} \mathrm{Th}\right)_{\mathrm{xs}}$ measured in the surface sediments and export production (Table 5; Figure 8). This positive relationship suggests that $\left({ }^{231} \mathrm{~Pa} /{ }^{230} \mathrm{Th}\right)_{\mathrm{xs}, 0}$ can be used as a paleoproductivity proxy in the EEP.

[32] In the WEP, Laws et al. [2000] model predicts export production lower than $12 \mathrm{~g}_{\mathrm{C} \mathrm{m}} \mathrm{yr}^{-1}$ (Table 5). These low values are inconsistent with the generally high $\left({ }^{231} \mathrm{~Pa} /{ }^{230} \mathrm{Th}\right)_{\mathrm{xs}, 0}$ ratios $(>0.093)$ measured in the core top of MD2138 and other cores from the surrounding area (Table 5; Figure 8). Three explanations could account for this discrepancy: (1) increased boundary scavenging resulting from higher influx of lithogenic material in the WEP from surrounding continental masses [e.g., Milliman et al., 1999], (2) underestimation of export productivity in the WEP by ocean color measurements from satellites or (3) control of the $\left({ }^{231} \mathrm{~Pa} /{ }^{230} \mathrm{Th}\right)_{\mathrm{xs}, 0}$ by the chemical composition of the sinking particles.

[33] Since ${ }^{232} \mathrm{Th}$ is exclusively associated with lithogenic material, it can be used as a proxy for lithogenic fluxes. Thus hypothesis (1) can be tested by comparing the surface $\left({ }^{231} \mathrm{~Pa} /{ }^{230} \mathrm{Th}\right)_{\mathrm{xs}}$ to the ${ }^{230} \mathrm{Th}$-normalized ${ }^{232} \mathrm{Th}$ flux in the same cores. As expected, there is a general eastward decreasing trend in ${ }^{232} \mathrm{Th}$ flux in the WEP (Table 6), reflecting a decrease in terrigenous flux away from lands. A similar trend is also recognized in sediment trap data [Kawahata et al., 2000]. This decrease is not matched, however, by a decrease in $\left({ }^{231} \mathrm{~Pa} /{ }^{230} \mathrm{Th}\right)_{\mathrm{xs}}$, which results in a total lack of correlation between $\left({ }^{231} \mathrm{~Pa} /{ }^{230} \mathrm{Th}\right)_{\mathrm{xs}}$ and the flux of ${ }^{232} \mathrm{Th}$, i.e., of lithogenic material (Figure 9a). Increased boundary scavenging due to high lithogenic flux fails to explain the high $\left({ }^{231} \mathrm{~Pa} /{ }^{230} \mathrm{Th}\right)_{\mathrm{xs}, 0}$ measured in MD2138. One possible explanation for the lack of correlation between $\left({ }^{231} \mathrm{~Pa} /{ }^{230} \mathrm{Th}\right)_{\mathrm{xs}}$ and satellite-derived estimates of export production in the WEP (Figure 8) is that the latter underestimate productivity (hypothesis 2). The validity of estimates of export productivity derived from ocean color in the WEP has been challenged by a global-scale comparison of organic carbon fluxes measured with deepsea moored sediment traps to export production derived from Laws et al. [2000] satellite-based algorithm. Results show that the latter might underestimate the settling flux of organic carbon reaching the bathypelagic zone in some areas which includes two data points from the WEP [François et al., 2002]. Sediment trap measurements also show that export biogenic fluxes are relatively high (8.5$47 \mathrm{~g} \mathrm{~m}^{-2} \mathrm{yr}^{-1}$ ) in the WEP [Kawahata et al., 2000]. However, the sediment trap database is too sparse to verify hypothesis (2). Thus if the WEP biogenic particle fluxes are $\sim 10 \mathrm{~g}_{\mathrm{C}} \mathrm{m}^{-2} \mathrm{yr}^{-1}$ as predicted by Laws et al. 
Table 5. Export Production (EP) Derived From Laws et al. [2000] and $\left({ }^{231} \mathrm{~Pa} /{ }^{230} \mathrm{Th}\right)_{\mathrm{xs}, 0}$ in the Surface Sediments From Sites in the Equatorial Pacific ${ }^{\mathrm{a}}$

\begin{tabular}{|c|c|c|c|c|}
\hline Core & $\begin{array}{c}\text { Longitude, } \\
-\mathrm{E} ;+\mathrm{W}\end{array}$ & $\begin{array}{c}\text { Latitude, } \\
-\mathrm{S} ;+\mathrm{N} \\
\end{array}$ & $\begin{array}{c}\mathrm{EP} \\
\mathrm{g}_{\mathrm{C}} / \mathrm{m}^{2} / \mathrm{y} \\
\end{array}$ & $\left({ }^{231} \mathrm{~Pa} /{ }^{230} \mathrm{Th}\right)_{\mathrm{xs}, 0}$ \\
\hline \multicolumn{5}{|c|}{ Eastern Equatorial Pacific (EEP) } \\
\hline V19-29 & -83.93 & -3.58 & 39.2 & 0.177 \\
\hline $\mathrm{P} 7 *$ & -83.99 & 2.61 & 19.6 & 0.250 \\
\hline V19-28 & -84.65 & -2.37 & 32.5 & 0.200 \\
\hline Y71-3-02 & -85.15 & 7.17 & 18.0 & 0.121 \\
\hline Y69-071P & -86.48 & 0.09 & 25.3 & 0.193 \\
\hline КH-71-5-42-2 & -88.05 & -27.58 & 14.0 & 0.054 \\
\hline VNTR01-16PC & -89.73 & 2.60 & 18.0 & 0.106 \\
\hline VNTR01-15GC* & -89.86 & 1.49 & 21.5 & 0.167 \\
\hline VNTR01-19PC & -90.44 & 7.91 & 24.5 & 0.136 \\
\hline VNTR01-13GC & -90.82 & -3.09 & 28.2 & 0.143 \\
\hline КH-71-5-44-2 & -93.35 & -20.84 & 14.9 & 0.025 \\
\hline VNTR01-21GC & -94.60 & 9.59 & 22.3 & 0.150 \\
\hline VNTR01-12GC & -95.07 & -3.01 & 28.2 & 0.119 \\
\hline VNTR01-11GC & -95.34 & 0.14 & 28.1 & 0.137 \\
\hline VNTR01-22GC & -99.37 & 13.01 & 18.5 & 0.154 \\
\hline KLH 068* & -101.61 & 1.23 & 20.5 & 0.167 \\
\hline VNTR01-10GC* & -102.02 & -4.51 & 20.3 & 0.128 \\
\hline KLH 093* & -102.06 & 1.23 & 20.4 & 0.181 \\
\hline MANOP $\mathrm{M}^{*}$ & -104.00 & 8.80 & 17.1 & 0.159 \\
\hline VNTR01-01PC & -109.61 & 11.25 & 14.7 & 0.056 \\
\hline VNTR01-03GC & -109.74 & 7.17 & 14.5 & 0.089 \\
\hline VNTR01-02PC & -109.75 & 7.19 & 14.5 & 0.073 \\
\hline VNTR01-04GC & -110.09 & 5.35 & 15.9 & 0.093 \\
\hline VNTR01-08PC & -110.48 & 0.04 & 22.5 & 0.113 \\
\hline VNTR01-09GC & -110.50 & -3.00 & 19.7 & 0.109 \\
\hline ODP849 & -110.52 & 0.20 & 22.3 & 0.116 \\
\hline VNTR01-06GC & -110.55 & 2.76 & 19.0 & 0.092 \\
\hline VNTR01-07GC & -110.57 & 1.02 & 21.0 & 0.116 \\
\hline VNTR01-05GC & -110.58 & 2.76 & 19.0 & 0.094 \\
\hline TT154-10* & -111.33 & -10.28 & 17.1 & 0.157 \\
\hline $154-10^{*}$ & -111.33 & -10.29 & 17.1 & 0.160 \\
\hline КH-71-5-53-2 & -112.70 & -8.26 & 17.5 & 0.080 \\
\hline $154-18^{*}$ & -113.86 & -20.03 & 12.4 & 0.199 \\
\hline $154-8^{*}$ & -113.87 & -10.81 & 16.9 & 0.110 \\
\hline V19-55* & -114.18 & -17.00 & 14.7 & 0.148 \\
\hline $154-19$ & -116.63 & -19.84 & 12.3 & 0.076 \\
\hline $154-20$ & -117.97 & -19.66 & 12.2 & 0.057 \\
\hline $154-6$ & -119.78 & -12.07 & 15.7 & 0.077 \\
\hline $154-5$ & -125.60 & -12.32 & 14.5 & 0.070 \\
\hline C57-58 & -125.91 & 15.16 & 15.4 & 0.034 \\
\hline $154-4$ & -134.85 & -12.62 & 13.4 & 0.037 \\
\hline MANOP C & -138.93 & 1.03 & 20.8 & 0.068 \\
\hline B52-39 & -139.07 & 11.25 & 15.0 & 0.033 \\
\hline MC112 & -139.64 & 5.08 & 17.3 & 0.048 \\
\hline MC69 & -139.74 & 0.12 & 21.4 & 0.070 \\
\hline MC34 & -140.00 & -5.00 & 17.0 & 0.060 \\
\hline MC27 & -140.00 & -3.00 & 17.7 & 0.050 \\
\hline MC19 & -140.00 & -2.00 & 19.0 & 0.060 \\
\hline RC11-210 & -140.05 & 1.82 & 20.1 & 0.071 \\
\hline MANOP S & -140.08 & 11.05 & 14.5 & 0.027 \\
\hline MC97 & -140.15 & 2.06 & 19.7 & 0.060 \\
\hline $1858358 \mathrm{bl}$ & -143.55 & 8.01 & 14.7 & 0.034 \\
\hline GIK10145-1 & -144.82 & 3.99 & 17.9 & 0.027 \\
\hline GIK10147-1 & -145.03 & 3.84 & 17.9 & 0.037 \\
\hline 10175 & -146.02 & 9.32 & 12.7 & 0.017 \\
\hline KH-71-5-12-3 & -146.03 & -11.02 & 14.1 & 0.091 \\
\hline $1858163 \mathrm{bl}$ & -146.03 & 9.27 & 12.7 & 0.027 \\
\hline $1858232 \mathrm{bl}$ & -146.05 & 9.35 & 12.7 & 0.034 \\
\hline $1858195 \mathrm{bl}$ & -146.09 & 9.67 & 12.4 & 0.023 \\
\hline $1858254 \mathrm{bl}$ & -146.09 & 9.33 & 12.8 & 0.031 \\
\hline GIK10149-1 & -146.16 & 9.51 & 12.6 & 0.035 \\
\hline KH-71-5-15-2 & -148.04 & -20.38 & 10.8 & 0.034 \\
\hline GIK10140-1 & -148.74 & 9.25 & 12.4 & 0.037 \\
\hline Valdivia 10141 & -148.78 & 9.11 & 12.5 & 0.028 \\
\hline GIK10141-1 & -148.78 & 9.11 & 12.5 & 0.029 \\
\hline GIK10132-1 & -148.96 & 6.22 & 16.2 & 0.032 \\
\hline
\end{tabular}

Table 5. (continued)

\begin{tabular}{lcrcc}
\hline \multicolumn{1}{c}{ Core } & $\begin{array}{c}\text { Longitude, } \\
-\mathrm{E} ;+\mathrm{W}\end{array}$ & $\begin{array}{r}\text { Latitude, } \\
-\mathrm{S} ;+\mathrm{N}\end{array}$ & $\begin{array}{c}\mathrm{EP}, \\
\mathrm{g}_{\mathrm{C}} / \mathrm{m}^{2} / \mathrm{y}\end{array}$ & $\left({ }^{231} \mathrm{~Pa} /{ }^{230} \mathrm{Th}\right)_{\mathrm{xs}, 0}$ \\
\hline V18-299 & -149.67 & -16.12 & 9.8 & 0.044 \\
1858 21 bl & -150.05 & 12.32 & 10.7 & 0.043 \\
1858 151 bl & -150.17 & 12.34 & 10.6 & 0.032 \\
A47-16 & -151.19 & 9.04 & 12.1 & 0.028 \\
KK1, core2 & -151.57 & 15.33 & 10.5 & 0.034 \\
10127-2 & -151.66 & 13.70 & 10.2 & 0.031 \\
Valdivia 10127 & -151.98 & 13.70 & 10.2 & 0.031 \\
KK1, core1 & -153.17 & 14.12 & 10.1 & 0.040 \\
V21-59 & -158.10 & 20.92 & 13.0 & 0.081 \\
210KG & -160.50 & -21.60 & 10.0 & 0.023 \\
214KG & -161.53 & -21.60 & 10.1 & 0.032 \\
G993 & -162.90 & -23.54 & 11.2 & 0.036 \\
V18-258 & -165.75 & -11.87 & 9.3 & 0.028 \\
& & & & \\
KH-79-1-5 & 130.47 & 5.18 & 12.0 & 0.095 \\
MD2138 & 146.40 & 1.70 & 10.9 & 0.129 \\
KH-79-4-6 & 147.62 & 23.79 & 10.7 & 0.022 \\
KH-79-4-7 & 153.72 & 10.79 & 8.2 & 0.033 \\
oj erdc bx88 & 155.87 & -0.05 & 10.3 & 0.087 \\
KH-79-4-8 & 156.14 & 5.01 & 9.0 & 0.026 \\
KH-79-4-9 & 158.11 & -0.29 & 9.9 & 0.123 \\
KH-79-4-22 & 158.60 & 20.05 & 9.0 & 0.040 \\
KH-79-4-10 & 159.31 & -3.32 & 10.3 & 0.175 \\
V28-238 & 160.48 & 1.02 & 9.8 & 0.067 \\
BC36 & 161.00 & 0.00 & 10.1 & 0.093 \\
oj erdc bx125 & 161.00 & -0.05 & 10.1 & 0.053 \\
KH-79-4-18 & 164.00 & -0.01 & 11.6 & 0.049 \\
KH-79-4-19 & 165.92 & 5.06 & 9.8 & 0.042 \\
KH-78-1-1036 & 176.95 & 8.01 & 9.8 & 0.031 \\
KH-78-1-1038 & 176.99 & 10.00 & 9.3 & 0.027 \\
\hline
\end{tabular}

${ }^{\mathrm{a}}$ See Walter et al. [1999, and references therein]. Asterisks denote cores located on/near the East Pacific Rise (EPR). Values are reported in Figure 8. Parentheses denote activity.

[2000] model, then they cannot generate the high $\left({ }^{231} \mathrm{~Pa} /{ }^{230} \mathrm{Th}\right)_{\mathrm{xs}}$ measured in the surface sediment of the area. The $\left({ }^{231} \mathrm{~Pa} /{ }^{230} \mathrm{Th}\right)_{\mathrm{xs}}$ ratios could therefore be increased by the preferential scavenging of ${ }^{231} \mathrm{~Pa}$ due to the chemical composition of the sinking particles (hypothesis 3). Sediment trap experiments have shown that opal is produced and exported in the WEP (about $20-30 \%$ of the total particle flux [Kawahata et al., 2000]) but is not preserved in the sediment. Chase et al. [2002, 2003a] have shown that the particle reactivity of ${ }^{231} \mathrm{~Pa}$ increase with the opal content and that ${ }^{230} \mathrm{Th}$ has the opposite behavior. Opal fluxes could therefore explain, at least partially, the high $\left({ }^{231} \mathrm{~Pa} /{ }^{230} \mathrm{Th}\right)_{\mathrm{xs}}$ ratios measured in the WEP sediments at Present. The $\mathrm{MnO}_{2}$ recorded in the surface of MD2138 could also explain the high $\left({ }^{231} \mathrm{~Pa} /{ }^{230} \mathrm{Th}\right)_{\mathrm{xs}}$ ratios since $\mathrm{MnO}_{2}$ does not fractionate ${ }^{231} \mathrm{~Pa}$ from ${ }^{230} \mathrm{Th}$. Therefore spatial variations in the opal and $\mathrm{MnO}_{2}$ fluxes could account for the geographical $\left({ }^{231} \mathrm{~Pa} /{ }^{230} \mathrm{Th}\right)_{\mathrm{xs}}$ variability recorded in the surface of the sediments. However, this hypothesis cannot be verified because of the lack of data. Alternatively, the lowest opal/carbonate ratios in the WEP are found at the equator [Kawahata et al., 2000] where the highest $\left({ }^{231} \mathrm{~Pa}{ }^{230} \mathrm{Th}\right)_{\mathrm{xs}}$ ratios are measured (Figure $\left.9 \mathrm{~b}\right)$. This behavior is opposite to what is expected from Chase et al. [2003a] results.

[34] To summarize, the high values of the $\left({ }^{231} \mathrm{~Pa} /{ }^{230} \mathrm{Th}\right)_{\mathrm{xs}}$ ratios measured in the surface sediments of the WEP could either be due to the composition of the particles (opal- or 


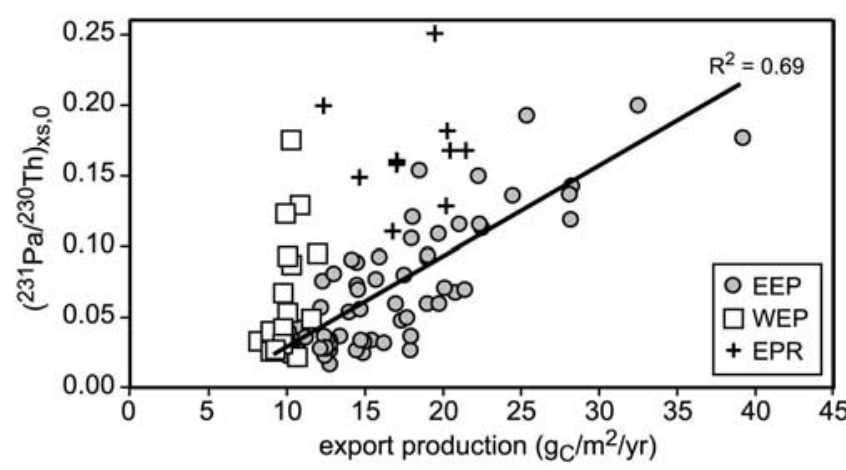

Figure 8. $\left({ }^{231} \mathrm{~Pa} /{ }^{230} \mathrm{Th}\right)_{\mathrm{xs}}$ measured in the surface sediments of the eastern (EEP) and western (WEP) equatorial Pacific versus export production estimated from ocean color measurements by satellite and a temperature-dependent ecosystem model [Laws et al., 2000]. Crosses indicate data from cores collected in the vicinity of the East Pacific Rise (EPR). They were not used in the regression because of possible high $\mathrm{MnO}_{2}$ concentration, which would have affected their $\left({ }^{231} \mathrm{~Pa}^{2}{ }^{230} \mathrm{Th}\right)_{\mathrm{xs}}$. There is a positive linear relationship between $\left({ }^{231} \mathrm{~Pa} /{ }^{230} \mathrm{Th}\right)_{\mathrm{xs}}$ and export production in the EEP $\left(\mathrm{R}^{2}=0.69\right)$. Source data are in Table 5 .

$\mathrm{MnO}_{2}$-rich or both) and/or to export fluxes higher than those determined by satellite-based models. The spatial variability of the $\left({ }^{231} \mathrm{~Pa} /{ }^{230} \mathrm{Th}\right)_{\mathrm{xs}}$ could be due to variations of the opal and/or $\mathrm{MnO}_{2}$ fluxes and/or to variations in the export production. Testing these hypotheses would require having much better constraints on the particle fluxes and their chemical compositions.

5.3. Downcore Variations in $\left({ }^{231} \mathrm{~Pa} / /^{230} \mathrm{Th}\right)_{\mathrm{xs}, 0}$ 5.3.1. Local Versus Remotely Induced Variations of the $\left({ }^{231} \mathrm{~Pa} /{ }^{230} \mathrm{Th}\right)_{\mathrm{xs}, 0}$

[35] We first have to discuss whether the observed glacial decrease in the $\left({ }^{231} \mathrm{~Pa} /{ }^{230} \mathrm{Th}\right)_{\mathrm{xs}, 0}$ in the WEP and the EEP are due to local or remote phenomenon. The generally stronger glacial winds [e.g., Parkin and Shackleton, 1973; Sarnthein et al., 1981] are likely to enhance the upwelling intensity on the western margins of the continents which would increase both productivity and eolian inputs in these areas. This phenomenon could increase the scavenging of ${ }^{231} \mathrm{~Pa}$ at the ocean margins therefore increasing the $\left({ }^{231} \mathrm{~Pa}{ }^{230} \mathrm{Th}\right)_{\mathrm{xs}, 0}$ ratios recorded in the underlying sediments. Consequently, more ${ }^{231} \mathrm{~Pa}$ would be advected from the adjacent regions which would be characterized by a decrease of the $\left({ }^{231} \mathrm{~Pa} /{ }^{230} \mathrm{Th}\right)_{\mathrm{xs}, 0}$ values during glacial times. Although the downcore $\left({ }^{231} \mathrm{~Pa} /{ }^{230} \mathrm{Th}\right)_{\mathrm{xs}, 0}$ database is very sparse for the Pacific, the few available data [Lao et al., 1992] show no significant glacial to Holocene $\left({ }^{231} \mathrm{~Pa} /{ }^{230} \mathrm{Th}\right)_{\mathrm{xs}, 0}$ changes at the western margins. The cores located at the eastern margins (Californian and the equatorial South American) show lower glacial $\left({ }^{231} \mathrm{~Pa} /{ }^{230} \mathrm{Th}\right)_{\mathrm{xs}, 0}$ ratios. These results are opposite to what is expected from enhanced glacial scavenging of ${ }^{231} \mathrm{~Pa}$ at the margins. Therefore the lower glacial $\left({ }^{231} \mathrm{~Pa} /{ }^{230} \mathrm{Th}\right)_{\mathrm{xs}, 0}$ measured in the WEP and the EEP appears to be due to local phenomenon rather than to remotely induced advection of ${ }^{231} \mathrm{~Pa}$ from the equatorial regions to the margins.
Table 6. $\left({ }^{231} \mathrm{~Pa} /{ }^{230} \mathrm{Th}\right)_{\mathrm{xs}, 0}$ and Fluxes of ${ }^{232} \mathrm{Th}$ in the WEP as Proxy for Lithogenic Input to the Sediment ${ }^{\mathrm{a}}$

\begin{tabular}{|c|c|c|c|c|}
\hline Core & $\begin{array}{c}\text { Longitude, } \\
\text { E }\end{array}$ & $\begin{array}{c}\text { Latitude, } \\
-\mathrm{S} ;+\mathrm{N}\end{array}$ & $\left({ }^{231} \mathrm{~Pa} /{ }^{230} \mathrm{Th}\right)_{\mathrm{xs}, 0}$ & $\begin{array}{c}{ }^{230} \mathrm{Th}-\text { Normalized } \\
{ }^{232} \mathrm{Th} \text { Fluxes, } \\
\mu \mathrm{g} / \mathrm{cm}^{2} / \mathrm{kyr}\end{array}$ \\
\hline КН-79-1-5 & 130.47 & 5.18 & 0.095 & 2.08 \\
\hline MD2138 & 146.40 & 1.70 & 0.129 & 1.30 \\
\hline КН-79-4-7 & 153.72 & 10.79 & 0.033 & 1.20 \\
\hline oj erdc bx 88 & 155.87 & -0.05 & 0.087 & 0.53 \\
\hline КH-79-4-8 & 156.14 & 5.01 & 0.026 & 0.48 \\
\hline КН-79-4-9 & 158.11 & -0.29 & 0.123 & 0.48 \\
\hline KH-79-4-10 & 159.31 & -3.32 & 0.175 & 0.83 \\
\hline V28-238 & 160.48 & 1.02 & 0.067 & 0.50 \\
\hline BC36 & 161.00 & 0.00 & 0.093 & 0.13 \\
\hline oj erdc bx 125 & 161.00 & -0.05 & 0.053 & 0.49 \\
\hline КH-79-4-18 & 164.00 & -0.01 & 0.049 & 0.62 \\
\hline КH-79-4-19 & 165.92 & 5.06 & 0.042 & 0.73 \\
\hline КН-78-1-1036 & 176.95 & 8.01 & 0.031 & 0.66 \\
\hline КН-78-1-1038 & 176.99 & 10.00 & 0.027 & 1.38 \\
\hline
\end{tabular}

${ }^{\mathrm{a}}$ Values are reported in Figure 9.

\subsubsection{Western Equatorial Pacific}

[36] $\left({ }^{231} \mathrm{~Pa} /{ }^{230} \mathrm{Th}\right)_{\mathrm{xs}, 0}$ is invariant on Ontong Java Plateau (core $\mathrm{BC} 36$ ) over the entire Holocene, suggesting very little changes in particle flux and composition at this site during the last $10 \mathrm{ka}$. The situation is different at the westernmost MD2138 site where we find a sharp mid-Holocene $\left({ }^{231} \mathrm{~Pa} /{ }^{230} \mathrm{Th}\right)_{\mathrm{xs}, 0}$ maximum (Figure 5). This longer record
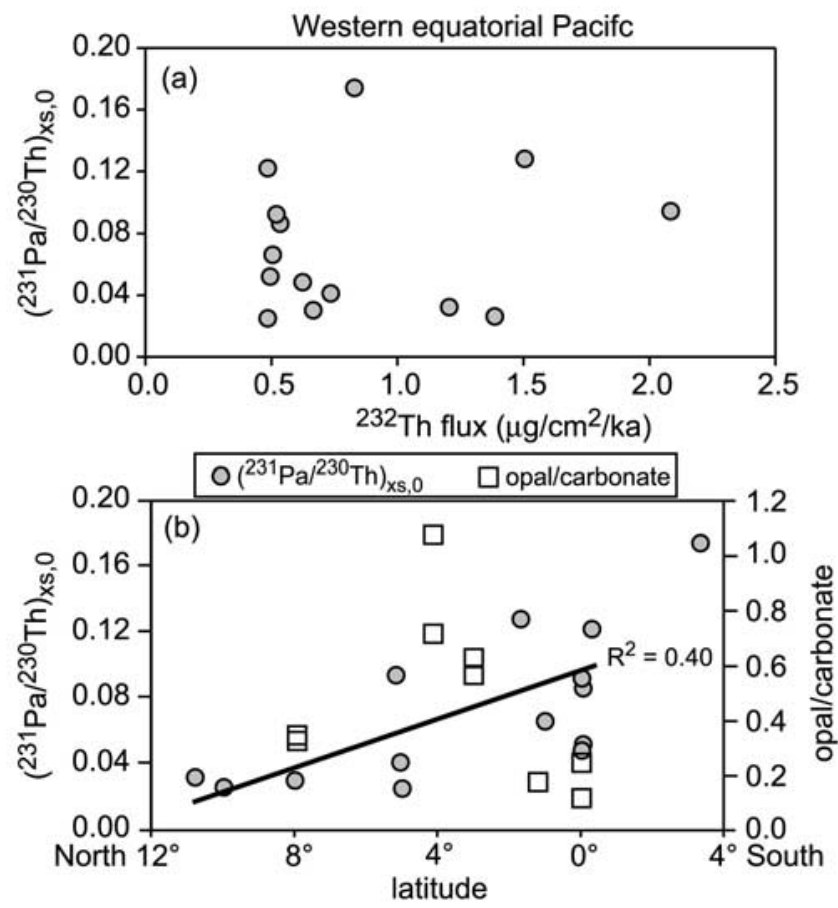

Figure 9. (a) $\left({ }^{231} \mathrm{~Pa} /{ }^{230} \mathrm{Th}\right)_{\mathrm{xs}}$ measured in the surface sediments of the western equatorial Pacific versus ${ }^{230} \mathrm{Th}$ normalized ${ }^{232} \mathrm{Th}$ fluxes used as a proxy for the fluxes of lithogenic material. (b) $\left({ }^{231} \mathrm{~Pa} /{ }^{230} \mathrm{Th}\right)_{\mathrm{xs}}$ measured in the surface sediments (Table 6) and opal/carbonate recorded in sediment traps [Kawahata et al., 2000] in the western equatorial Pacific versus latitude. There is a decrease of the $\left({ }^{231} \mathrm{~Pa} /{ }^{230} \mathrm{Th}\right)_{\mathrm{xs}}$ values from the equator to the north. 

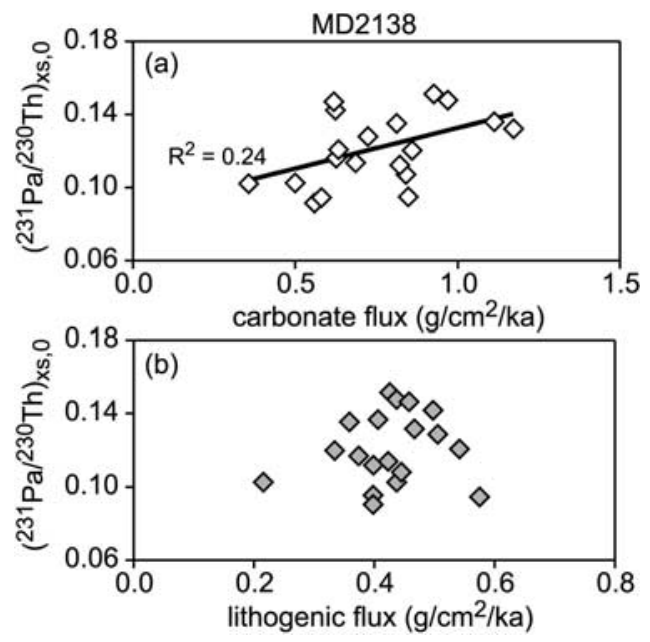

Figure 10. $\left({ }^{231} \mathrm{~Pa} /{ }^{230} \mathrm{Th}\right)_{\mathrm{xs}, 0}$ versus (a) ${ }^{230} \mathrm{Th}$-normalized carbonate fluxes and (b) ${ }^{230}$ Th-normalized lithogenic fluxes measured downcore in MD2138.

also documents clear minima during the colder IS2 and IS4, and higher values during IS3 and IS5a.

[37] The lack of constraints on the paleoceanography of the WEP and the complex geological and oceanographic settings of the region render the finding of an unique explanation that could account for the $\left({ }^{231} \mathrm{~Pa} /{ }^{230} \mathrm{Th}\right)_{\mathrm{xs}, 0}$ variations difficult. In the following paragraphs, we discuss various hypotheses that could explain the lower glacial $\left({ }^{231} \mathrm{~Pa} /{ }^{230} \mathrm{Th}\right)_{\mathrm{xs}, 0}$ ratios measured in MD2138.

[38] As proposed in section 5.1., the variations of the $\left({ }^{231} \mathrm{~Pa} /{ }^{230} \mathrm{Th}\right)_{\mathrm{xs}, 0}$ ratio in MD2138 could be due to a change in the chemical composition of the settling particles. The high sediment focusing factors observed in MD2138 (Table 4) could be explained by downslope transport given that the core is located at the foot of a continental slope. Particles with relatively high $\mathrm{MnO}_{2}$ concentrations could have been resuspended from shallower depths during the downslope transport. $\mathrm{MnO}_{2}$-rich particles scavenge dissolved ${ }^{230} \mathrm{Th}$ and ${ }^{231} \mathrm{~Pa}$ with the same efficiency. Consequently, the $\left({ }^{231} \mathrm{~Pa} /{ }^{230} \mathrm{Th}\right)_{\mathrm{xs}, 0}$ ratios in MD2138 would be increased if the resuspended particles have spent a substantial amount of time in the water column before their final burial at the core site. If sediment focusing is interpreted in terms of downslope transport, when sediment focusing increase, higher fluxes of $\mathrm{MnO}_{2}$ are expected and accordingly higher $\left({ }^{231} \mathrm{~Pa} /{ }^{230} \mathrm{Th}\right)_{\mathrm{xs}, 0}$ ratios. However, the continuous increase of sediment focusing from IS5 to IS3 (Figure 7) is not matched by an increase of the $\left({ }^{231} \mathrm{~Pa} /{ }^{230} \mathrm{Th}\right)_{\mathrm{xs}, 0}$ ratios (Figure 5). Similarly, from IS2 to the Holocene, sediment focusing decreased and $\left({ }^{231} \mathrm{~Pa} /{ }^{230} \mathrm{Th}\right)_{\mathrm{xs}, 0}$ ratios increased while the opposite behavior is expected. The downslope transport of $\mathrm{MnO}_{2}$-rich particles could therefore explain that $\left({ }^{231} \mathrm{~Pa} /{ }^{230} \mathrm{Th}\right)_{\mathrm{xs}, 0}$ values in MD2138 are generally higher than 0.093 but this phenomenon could not account for the temporal variations of the $\left({ }^{231} \mathrm{~Pa} /{ }^{230} \mathrm{Th}\right)_{\mathrm{xs}, 0}$ ratios.

[39] The $\left({ }^{231} \mathrm{~Pa} /{ }^{230} \mathrm{Th}\right)_{\mathrm{xs}, 0}$ maxima found in the Holocene, IS3 and IS5a coincide with maxima in ${ }^{230}$ Th-normalized carbonate flux (Figure 6), suggesting a productivity control. The relatively shallow depth at which this core was taken $(1900 \mathrm{~m})$ is well above the calcite saturation horizon in the water column of this region $(\sim 3000 \mathrm{~m})$ and likely to be outside the range of depth variability of the saturation horizon over the time considered. Therefore variability in sedimentary calcite fluxes in this core should mainly reflect variations in carbonate production unaffected by variations in carbonate preservation. In addition, there is a weak correlation between downcore variations in $\left({ }^{231} \mathrm{~Pa} /{ }^{230} \mathrm{Th}\right)_{\mathrm{xs}, 0}$ and carbonate fluxes $\left(\mathrm{R}^{2}=0.24\right)$, while none exist with lithogenic fluxes (Figure 10). The $\left({ }^{231} \mathrm{~Pa} /{ }^{230} \mathrm{Th}\right)_{\mathrm{xs}, 0}$ record of MD2138 thus suggests lower carbonate export production and particle flux in the WEP during glacial periods. Chase et al. [2002, 2003a] have recently argued that the $\left({ }^{231} \mathrm{~Pa} /{ }^{230} \mathrm{Th}\right)_{\mathrm{xs}, 0}$ variability is mainly controlled by variations in the opal/carbonate ratio of the sinking particles. We cannot rule out the possibility that, in addition to lower export production by carbonate-producing phytoplankton, $\left({ }^{231} \mathrm{~Pa} /{ }^{230} \mathrm{Th}\right)_{\mathrm{xs}, 0}$ may also have been partly lowered by a decrease of the opal/carbonate ratio of the sinking particles which then would correspond to a drop in diatom production. There are only negligible amounts of preserved opal in MD2138. However, at Present, the biogenic opal produced in the WEP $(20-30 \%$ of the vertical particle flux [Kawahata et al., 2000]) is not preserved in the sediment. If the same behavior holds for the past, the high $\left({ }^{231} \mathrm{~Pa} /{ }^{230} \mathrm{Th}\right)_{\mathrm{xs}, 0}$ ratios could also be explained by the preferential scavenging of ${ }^{231} \mathrm{~Pa}$ relative to ${ }^{230} \mathrm{Th}$ induced by opal [Chase et al., 2002, 2003a]. Further studies are needed to constrain the variations of the chemical composition and intensity of the biogenic fluxes. However, our study tends to show a decrease of the exported carbonate, and possibly opal, fluxes during IS2 and IS4 in the WEP.

\subsubsection{Eastern Equatorial Pacific}

[40] $\left({ }^{231} \mathrm{~Pa} /{ }^{230} \mathrm{Th}\right)_{\mathrm{xs}, 0}$ values are generally lower at ODP site 849 compared to the western site (MD2138). However, the variability in the ratio is very similar in both cores, with lower values during the colder periods (IS2 and IS4) and higher values during the warmer periods (Holocene, IS3 and IS5a). The main difference is a broader Holocene maximum in the eastern Pacific core (Figure 5). The slight delay found during IS4 could result from uncertainties in the core chronology. In contrast to core MD2138, the $\left({ }^{231} \mathrm{~Pa} /{ }^{230} \mathrm{Th}\right)_{\mathrm{xs}, 0}$ profile in ODP849 does not fully mimic the variations of the ${ }^{230} \mathrm{Th}$-normalized carbonate flux (Figure 6). The sharp increase of $\left({ }^{231} \mathrm{~Pa} /{ }^{230} \mathrm{Th}\right)_{\mathrm{xs}, 0}$ between 60 and $50 \mathrm{ka}$ is associated to an increase of the ${ }^{230} \mathrm{Th}$ normalized carbonate flux. However, this is not true for the $\left({ }^{231} \mathrm{~Pa} /{ }^{230} \mathrm{Th}\right)_{\mathrm{xs}, 0}$ increase at the last deglaciation. ODP849 was collected at greater depth $(3800 \mathrm{~m})$ than MD2138, well below the saturation horizon. Therefore variations in the preserved carbonate rain rate reconstructed by ${ }^{230} \mathrm{Th}$ normalization not only reflect changes in carbonate production, but also changes in carbonate preservation resulting from changes in the depth of the lysocline [e.g., Farrell and Prell, 1989]. In further contrast to the western site, some opal is preserved in sediments deposited at the ODP849 site (Figure 3). The variability in preserved opal rain rates 


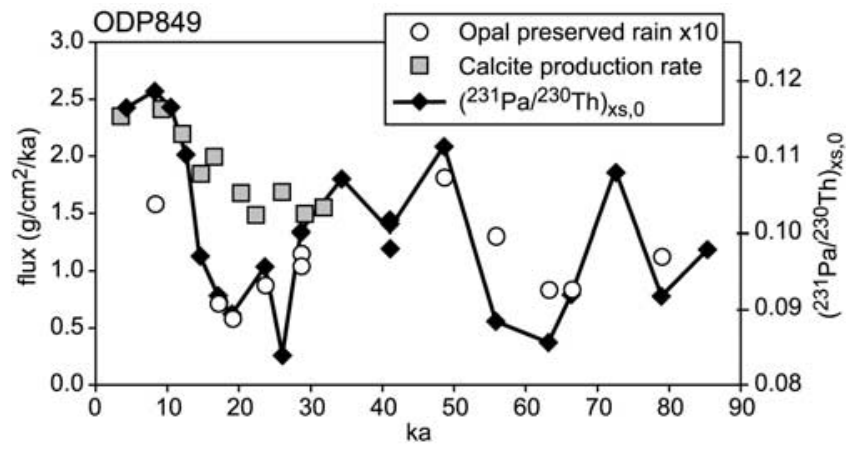

Figure 11. $\left({ }^{231} \mathrm{~Pa} /{ }^{230} \mathrm{Th}\right)_{\mathrm{xs}, 0},{ }^{230} \mathrm{Th}$-normalized preserved opal fluxes, and carbonate production rate in ODP849. Carbonate production rates were obtained by combining ${ }^{230}$ Th-normalized preserved carbonate fluxes and quantitative estimates of carbonate dissolution from a $G$. menardii fragmentation transfer function [Loubere et al., 2004].

measured in this core is very similar to the $\left({ }^{231} \mathrm{~Pa} /{ }^{230} \mathrm{Th}\right)_{\mathrm{xs}, 0}$ record (Figure 11). This observation and the broad correlation that we find between satellite-derived export production and $\left({ }^{231} \mathrm{~Pa} /{ }^{230} \mathrm{Th}\right)_{\mathrm{xs}}$ in the surface sediment of the EEP (Figure 8) suggest that the low glacial $\left({ }^{231} \mathrm{~Pa} /{ }^{230} \mathrm{Th}\right)_{\mathrm{xs}, 0}$ is due to lower export productivity. Lower carbonate production rates during IS2 were also obtained from the same core (Figure 11) by Loubere et al. [2004] after combining ${ }^{230}$ Th-normalized preserved carbonate fluxes and quantitative estimates of carbonate dissolution from a $G$. menardii fragmentation transfer function [Mekik et al., 2002]. Both approaches point to lower glacial productivity, for both carbonate and opal producing plankton, at ODP Site 849.

\subsection{Comparison With Previous Studies of Paleoproductivity in the Equatorial Pacific}

[41] $\left({ }^{231} \mathrm{~Pa} /{ }^{230} \mathrm{Th}\right)_{\mathrm{xs}, 0}$ (Figure 5), calcite production rates [Loubere et al., 2004], and ${ }^{230}$ Th-normalized fluxes of preserved opal (Figure 11) consistently suggest lower glacial productivity in the western and eastern equatorial Pacific. Lower glacial productivity in the EEP is consistent with recent paleoproductivity reconstructions in this region using a new transfer function based on benthic foraminifera assemblages [Loubere, 1999, 2000, 2001, 2003], but contrary to conclusions derived from mass accumulation rates of biogenic material [Lyle et al., 1988; Sarnthein et al., 1988; Paytan et al., 1996]. It is becoming increasingly evident that mass accumulation rates (MAR) of biogenic material on the seafloor can be significantly affected by sediment redistribution by bottom currents [Marcantonio et al., 2001; François et al., 2004; Loubere et al., 2004]. In particular, the study by Marcantonio et al. [2001] showed that most of the variability in barite MAR in the central equatorial Pacific is eliminated by normalizing the barite flux to ${ }^{230} \mathrm{Th}_{\mathrm{xs}, 0}$. Preserved calcite MAR in ODP849 is significantly higher at the LGM than during the Holocene. However, Loubere et al. [2004] study showed that the difference vanishes when using ${ }^{230} \mathrm{Th}_{\mathrm{xs}, 0}$-normalized calcite flux. The MAR values calculated in ODP849 $\left(1.7-2.4 \mathrm{~g} / \mathrm{cm}^{2} / \mathrm{ka}\right)$ are $2-3.5$ times higher than the ${ }^{230} \mathrm{Th}_{\mathrm{xs}, 0}$-normalized total flux $\left(0.5-1.2 \mathrm{~g} / \mathrm{cm}^{2} / \mathrm{ka}\right)$ (Figure 12). In particular, during IS2, ${ }^{230} \mathrm{Th}_{\mathrm{xs}, 0}$-normalized total flux decreases by $15 \%$ whereas MAR exhibits a $25 \%$ increase. This latter appears to be mostly due to the glacial increase of sediment focusing (Figure 7). These studies suggest that variations in MAR in the equatorial Pacific mainly reflect variability in sediment focusing rather than changes in particle flux from the overlying surface water. Our $\left({ }^{231} \mathrm{~Pa} /{ }^{230} \mathrm{Th}\right)_{\mathrm{xs}, 0}$ profiles together with the high focusing values we calculated in ODP849 support this interpretation and point out the necessity of using ${ }^{230} \mathrm{Th}_{\mathrm{xs}, 0}$-normalization rather than MAR to reconstruct export fluxes.

\subsection{Implications From Lower Glacial Productivity in the WEP and the EEP}

[42] Lower glacial productivity shown in our study could suggest that the El Nino climatic mode would be more prominent during glacial periods. This interpretation is consistent with smaller SST gradients and lower equatorial upwelling rates reported by Koutavas et al. [2002] and modeling studies of Clement et al. [1999]. However, irrespective of the intensity of the Trade Winds and the equatorial upwelling rate, lower productivity could also result from lower nutrient concentrations in the EUC which supply nutrient to the equatorial divergence and the SEC [e.g., Loubere, 1999; Spero and Lea, 2002]. Various hypotheses could account for lower nutrient concentrations in the EUC. For instance, upwelling of Fe-rich waters from the EUC has been proposed as a major source of Fe to the EEP [Gordon et al., 1997]. Fe in the EUC originates from the interaction between the New Guinea coastal undercurrent (NGCU) and the continental shelf of Papua New Guinea [Mackey et al., 2002] where great loads of continental inputs occur (860 t/yr [Milliman et al., 1999]). During the last glacial maximum the seawater level has dropped by 100-120 m [Lambeck and Chappell, 2001, and references therein]. Consequently, the interaction between

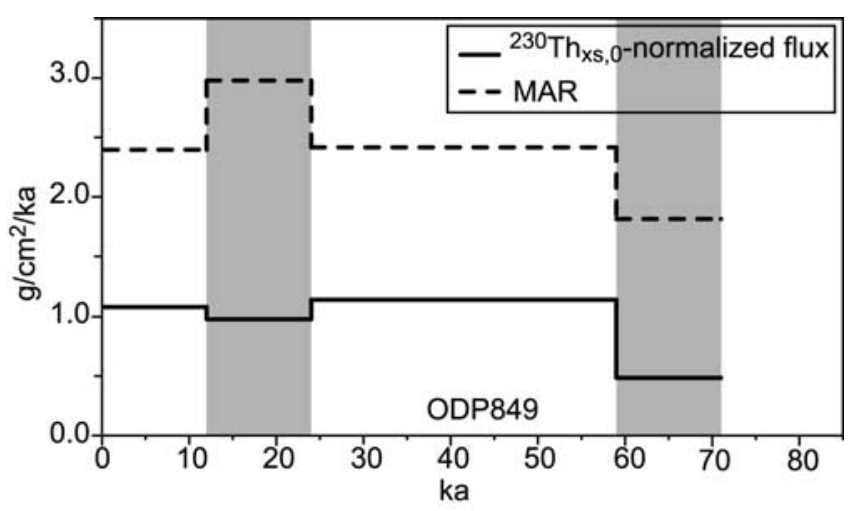

Figure 12. ${ }^{230}$ Th-normalized total flux (or preserved vertical rain rate) and marine accumulation rate (MAR) averaged over each isotopic stage in ODP849. Glacial periods (isotopic stages 2 and 4) are shown in light gray [Martinson et al., 1987]. 
the NGCU and the Papua New Guinea continental shelf could have been reduced potentially bringing less $\mathrm{Fe}$ into the EUC. Recently, Loubere [1999], Matsumoto et al. [2002] and Brzezinski et al. [2002] have argued for lower nitrate and higher silicate concentrations in the glacial EUC. They proposed a Fe-induced increase in the nitrate/silicate uptake ratio in the surface water of the Southern Ocean from where the deeper part of the EUC originates [Toggweiler et al., 1991; Rodgers et al., 2003]. They postulate that such an increase could have resulted in a higher supply of silicate to the EEP via the EUC thereby increasing diatom production and the organic carbon/carbonate rain ratio. Consequently, the surface water alkalinity would have increased thus contributing to the glacial drawdown of atmospheric $\mathrm{CO}_{2}$ (silicic acid leakage hypothesis). Sea surface cooling in the tropics would have also provided an abiotic contribution to this drawdown. The $\left({ }^{231} \mathrm{~Pa}^{230} \mathrm{Th}\right)_{\mathrm{xs}, 0}$ and ${ }^{230} \mathrm{Th}$-normalized fluxes of preserved opal from ODP849 suggest lower diatom productivity during glacial periods, which seems to challenge the silicic acid leakage hypothesis. However, deriving a conclusion from a single core may be premature given the large regional variability of the productivity response to glacial climate that characterize the EEP [Loubere, 2000, 2003]. At ODP Site $846\left(3.1^{\circ} \mathrm{S}, 90.8^{\circ} \mathrm{W}\right)$, located west of ODP849 under the SEC, there are preliminary evidence for higher opal preserved rain rate during the last glacial period, higher rain ratio and lower overall productivity (P. Loubere et al., manuscript in preparation, 2004). Fully evaluating the validity of the silicic acid leakage hypothesis and verifying whether El Nino is an adequate description of the oceanographic setting of the glacial equatorial Pacific will therefore require detailed synoptic reconstructions of primary production and SST over the entire equatorial Pacific region.

\section{Conclusions}

[43] This study shows similar variations in $\left({ }^{231} \mathrm{~Pa} /\right.$ $\left.{ }^{230} \mathrm{Th}\right)_{\mathrm{xs}, 0}$ in two sediment cores from the western (MD2138) and eastern (ODP849) equatorial Pacific with systematically lower values during isotopic stages 2 and 4 , i.e., glacial periods. Given the lack of data and constraints on the paleoceanography of the western equatorial Pacific, the conclusions drawn from our study of core MD2138 are still ambiguous. The generally high $\left({ }^{231} \mathrm{~Pa} /{ }^{230} \mathrm{Th}\right)_{\mathrm{xs}, 0}$ ratios measured in MD2138 could be due to opal fluxes that are not preserved in the sediment and/or $\mathrm{MnO}_{2}$ fluxes of downslope transported particles. Alternatively, although this hypothesis is questionable with Present data, the export production could have been high enough to explain the generally high $\left({ }^{231} \mathrm{~Pa} /{ }^{230} \mathrm{Th}\right)_{\mathrm{xs}, 0}$. Variations in downslope transport of $\mathrm{MnO}_{2}$ particles cannot explain the variations in the $\left({ }^{231} \mathrm{~Pa} /{ }^{230} \mathrm{Th}\right)_{\mathrm{xs}, 0}$ profile. The study of ${ }^{230}$ Th-normalized carbonate flux variations show a decrease in export biogenic carbonate that could explain the glacial decrease of $\left({ }^{231} \mathrm{~Pa} /{ }^{230} \mathrm{Th}\right)_{\mathrm{xs}, 0}$. Lower opal/carbonate ratios, i.e., a decrease in the exported opal flux, could also account for the lower $\left({ }^{231} \mathrm{~Pa} /{ }^{230} \mathrm{Th}\right)_{\mathrm{xs}, 0}$ glacial values. Although in need of confirmation, our study tends to show a decrease of export production (carbonate and/or opal) during glacial periods in the western equatorial Pacific.

[44] Combined with profiles of elemental composition and ${ }^{230} \mathrm{Th}_{\mathrm{xs}}$-normalized fluxes, the $\left({ }^{231} \mathrm{~Pa} /{ }^{230} \mathrm{Th}\right)_{\mathrm{xs}, 0}$ variations in the eastern equatorial Pacific can be interpreted as reflecting lower export production during glacial periods. Our conclusions for the EEP are in agreement with recently developed proxies that are insensitive to dissolution or sediment redistribution processes [Loubere et al., 2004].

[45] There is significant sediment focusing at the two study sites. Particularly, there is higher focusing during glacial periods in the eastern equatorial Pacific. Our results, together with conclusions from previous studies [Marcantonio et al., 2001; Loubere et al., 2004] highlight the necessity of using ${ }^{230} \mathrm{Th}$-normalization instead of mass accumulation rates (MAR) to reconstruct past changes in export flux, in particular biogenic paleofluxes.

[46] Acknowledgments. We thank Lary Ball and the WHOI ICP Facility for use of their Finnigan MAT ELEMENT SF-ICP-MS and their Jobin Yvon JY38VHR ICP-OES. We thank Steve Manganini for performing analyses of oxides. Alan Fleer is thanked for his help in the laboratory. We thank Luc Beaufort for his help while sampling IMAGES core MD97-2138 at the CEREGE (France) core repository and Dan McCorkle for his help at the WHOI (USA) core repository. Bob Anderson, Marcus Christl, Gideon Henderson and Augusto Mangini are thanked for their very constructive reviews. SP funding for this research was provided by grants from the French Minister of Research and a EURODOC grant of the Région Rhône-Alpes (SAFIR-980065327). SP also gratefully acknowledges the financial support of the WHOI Geology and Geophysics Dept. This work was also supported by a CNRS-NSF grant (SP and KWWS). The contribution of JFM to this study was supported in part by the US NSF and by WHOI OCCI and Mellon awards. This is WHOI contribution 11054

\section{References}

Anderson, R. F., M. P. Bacon, and P. G Brewer (1983a), Removal of ${ }^{230} \mathrm{Th}$ and ${ }^{231} \mathrm{~Pa}$ from the open ocean, Earth Planet. Sci. Lett., 62, 7-23.

Anderson, R. F., M. P. Bacon, and P. G. Brewer (1983b), Removal of ${ }^{230} \mathrm{Th}$ and ${ }^{231} \mathrm{~Pa}$ from the ocean margins, Earth Planet. Sci. Lett., 66, 73-90.

Anderson, R. F., Y. Lao, W. S. Broecker, S. E. Trumbore, H. J. Hofmann, and W. Wolfli (1990), Boundary scavenging in the Pacific Ocean: A comparison of ${ }^{10} \mathrm{Be}$ and ${ }^{231} \mathrm{~Pa}$, Earth Planet. Sci. Lett., 96, 287-304.
Andreasen, D. H., A. C. Ravelo, and A. J Broccoli (2001), Remote forcing at the Last Glacial Maximum in the tropical Pacific Ocean, J. Geophys. Res., 106(C1), 879897.

Andreasen, D. J., and A. C. Ravelo (1997), Tropical Pacific Ocean thermocline depth reconstructions for the last glacial maximum, Paleoceanography, 12, 395-413.

Bacon, M. P. (1984), Glacial to interglacia changes in carbonate and clay sedimentation in the Atlantic Ocean estimated from ${ }^{230} \mathrm{Th}$ measurements, Isot. Geosci., 2, 97-111.
Bacon, M. P. (1988), Tracers of chemical scavenging in the ocean: Boundary effects and large-scale chemical fractionation, Philos. Trans. R. Soc. London Ser. A, 325 $147-160$.

Bacon, M. P., and J. N. Rosholt (1982), Accumulation rates of ${ }^{230} \mathrm{Th},{ }^{231} \mathrm{~Pa}$, and some transition metals on the Bermuda Rise, Geochim. Cosmochim. Acta, 46, 651-666.

Barnes, C. E., and J. K. Cochran (1990), Uranium removal in oceanic sediments and the oceanic U balance, Earth Planet. Sci. Lett. 97, 94-101. 
Beaufort, L., T. de Garidel-Thoron, A. C. Mix, and N. G. Pisias (2001), ENSO-like forcing on oceanic primary production during the late Pleistocene, Science, 293, 2440-2444.

Berelson, W. M., R. F. Anderson, J. Dymond, D. Demaster, D. E. Hammond, R. Collier, S. Honjo, M. Leinen, J. McManus, and R. Pope (1997), Biogenic budgets of particle rain, benthic remineralization and sediment accumulation in the equatorial Pacific, Deep Sea Res. Part II, 44, 2251-2282.

Brewer, P. G. (1975), Minor elements in seawater, in Chemical Oceanography, vol. 1, edited by J. P. Riley and G. Skirrow, pp. 415-496, Academic, San Diego, Calif.

Brewer, P. G., Y. Nozaki, D. W. Spencer, and A. P. Fleer (1980), Sediment trap experiments in the deep North Atlantic: Isotopic and elemental fluxes, J. Mar. Res., 38, 703-728.

Broecker, W. S. (1979), A revised estimates for the radiocarbon age of the north Atlantic deep water, J. Geophys. Res., 84, 3218-3226.

Broecker, W. S., and H.-S. Peng (1982), Tracers in the Sea, 690 pp., Lahmont-Doherty Earth Obs., Palisades, N. Y.

Broecker, W. S., E. Clark, D. C. McCorkle, I. Hajdas, and G. Bonani (1999), Core top ${ }^{14} \mathrm{C}$ ages as a function of latitude and water depth on the Ontong-Java plateau, Paleoceanography, 14, 13-22.

Brzezinski, M. A., C. J. Pride, V. M. Franck, D. M. Sigman, J. L. Sarmiento, K. Matsumoto, N. Gruber, G. H. Rau, and K. H. Coale (2002), A switch from $\mathrm{Si}(\mathrm{OH})_{4}$ to $\mathrm{NO}_{3}^{-}$depletion in the glacial Southern Ocean, Geophys. Res. Lett., 29(12), 1564, doi:10.1029/2001GL014349.

Bush, A. B., and S. G. Philander (1999), The climate of the last glacial maximum: Results from a coupled atmosphere-ocean general circulation model, J. Geophys. Res., 104(D20), $24,509-24,525$

Cane, M. A. (1998), A role for the tropical Pacific, Science, 282, 59-61.

Cane, M. A., and A. C. Clement (1999), A role for the tropical Pacific coupled ocean-atmospheresystem on Milankovich and millennial timescales: 2. Global impacts, in Mechanisms of Millennial Scale Global Climate Change, Geophys. Monogr. Ser., vol. 112, edited by P. U. Clark, R. S. Webb, and L. D. Keigwin, pp. 373-383, AGU, Washington, D. C.

Chase, Z., R. F. Anderson, M. Q. Fleisher, and P. W. Kubik (2002), The influence of particle composition and particle flux on scavenging of $\mathrm{Th}, \mathrm{Pa}$ and $\mathrm{Be}$ in the ocean, Earth Planet. Sci. Lett., 204, 215-229.

Chase, Z., R. F. Anderson, M. Q. Fleisher, and P. W. Kubik (2003a), Accumulation of biogenic and lithogenic material in the Pacific sector of the Southern Ocean during the past 40,000 years, Deep Sea Res. Part II, 50, $799-832$.

Chase, Z., R. F. Anderson, M. Q. Fleisher, and P. W. Kubik (2003b), Scavenging of ${ }^{230} \mathrm{Th}$, ${ }^{231} \mathrm{~Pa}$ and ${ }^{10} \mathrm{Be}$ in the Southern Ocean (SW Pacific sector): The importance of particle flux, particle composition and advection, Deep Sea Res. Part II, 50, 739-768.

Chen, J. H., R. L. Edwards, and G. J. Wasserburg (1986), ${ }^{238} \mathrm{U}_{-}{ }^{234} \mathrm{U}_{-}{ }^{232} \mathrm{Th}$ in seawater, Earth Planet. Sci. Lett., 80, 241-251.

Choi, M. S., R. François, K. W. W. Sims, M. P. Bacon, S. Brown-Leger, A. P. Fleer, L. A. Ball, D. Schneider, and S. Pichat (2001), Rapid determination of ${ }^{230} \mathrm{Th}$ and ${ }^{231} \mathrm{~Pa}$ in seawater by desolvated micro-nebulization Inductively Coupled Plasma magnetic sector mass spectrometry, Mar. Chem., 76, 99-112.
Clement, A. C., R. Seager, and M. A. Cane (1999), Orbital controls on the El Niño/Southern Oscillation and the tropical climate, Paleoceanography, 14, 441-456.

Deuser, W. G. (1975), Reducing environments, in Chemical Oceanography, edited by J. P. Riley and G. Skirrow, pp. 1-37, Academic, San Diego, Calif.

Farrell, J. W., and W. L. Prell (1989), Climate change and $\mathrm{CaCO}_{3}$ preservation: An 80,0000 year bathymetric reconstruction from the central equatorial Pacific Ocean, Paleoceanography, 4, 447-466.

Feldberg, M. J., and A. C. Mix (2003), Planktonic foraminifera, sea surface temperatures, and mechanisms of oceanic change in the Peru and south equatorial currents, $0-150 \mathrm{ka} \mathrm{BP}$, Paleoceanography, 18(1), 1016, doi:10.1029/ 2001PA000740.

Fleer, A. P., and M. P. Bacon (1991), Notes on some techniques of marine particle analysis used at WHOI, in Marine Particles: Analysis and Characterization, Geophys. Monograph Ser., vol. 63, edited by D. C. Hurd and D. W. Spencer, pp. 223-226, AGU, Washington, D. C

François, R., and M. P. Bacon (1991), Variations in terrigenous input to the deep equatorial Atlantic during the past 24,000 years, Science, $251,1473-1476$.

François, R., M. P. Bacon, and D. O. Suman (1990), ${ }^{230}$ Th profiling in deep-sea sediments: High resolution records of flux and dissolution of carbonate in the equatorial Atlantic during the last 24,000 years, Paleoceanography, 5, $761-787$.

François, R., M. P. Bacon, M. A. Altabet, and L. D. Labeyrie (1993), Glacial/interglacial changes in sediment rain rate in the Indian sector of Subantarctic water as recorded by ${ }^{230} \mathrm{Th},{ }^{231} \mathrm{~Pa}, \mathrm{U}$, and ${ }^{15} \mathrm{~N}$, Paleoceanography, $8,611-629$.

François, R., M. A. Altabet, E.-F. Yu, D. M. Sigman, M. P. Bacon, M. Frank, G. Bohrmann, G. Bareille, and L. D. Labeyrie (1997), Water column stratification in the Southern Ocean contributed to the lowering of glacial atmospheric $\mathrm{CO}_{2}$, Nature, 389, 929-935.

François, R., S. Honjo, R. Krishfield, and S. Manganini (2002), Factors controlling the flux of organic carbon to the bathypelagic zone of the ocean, Global Biogeochem Cycles, 16(4), 1087, doi:10.1029/ 2001 GB001722.

François, R., M. Frank, M. M. Rutgers van der Loeff, and M. P. Bacon (2004), ${ }^{230}$ Th normalization: An essential tool for interpreting sedimentary fluxes during the late Quaternary, Paleoceanography, 19, PA1018, doi:10.1029/ 2003PA000939.

Frank, M., J.-D. Eckhardt, A. Eisenhauer, P. W. Kubik, B. Dittrich-Hannen, M. Segl, and A. Mangini (1994), Beryllium 10, Thorium 230, and Protactinium 231 in Galapagos microplate sediments: Implications of hydrothermal activity and paleoproductivity changes during the last 10,0000 years, Paleoceanography, 9, $559-578$.

Frank, M., R. Gersonde, and A. Mangini (1999), Sediment redistribution, 230Thex-normalization and implications for the reconstruction of particle flux and export paleoproductivity, in Use of proxies in Paleoceanography: Examples From the South Atlantic, edited by G. Fischer and G. Wefer, pp. 410-426, Springer-Verlag, New York.

Gill, J. B., J. D. Morris, and R. W. Johnson (1993), Timescale for producing the geochem- ical signature of island arc magmas: U-Th-Po and Be-B systematics in recent Papua New Guinea lavas, Geochim. Cosmochim. Acta, 57, 4269-4283.

Gordon, R. M., K. H. Coale, and K. S. Johnson (1997), Iron distribution in the equatorial Pacific: Implications for new production, Limnol. Oceanogr., 141, 419-431.

Henderson, G. M., C. Heinze, R. F. Anderson, and A. M. E. Winguth (1999), Global distribution of the ${ }^{230} \mathrm{Th}$ flux to ocean sediments constrained by GCM modeling, Deep Sea Res., 46, 1861-1893.

Huh, C.-A., and T. M. Beasley (1987), Profiles of dissolved and particulate thorium isotopes in the water column of coastal southern California, Earth Planet. Sci. Lett., 85, 1-10.

Imbrie, J., J. D. Hays, D. G. Martinson, A. McIntyre, A. C. Mix, J. J. Morley, N. G. Pisias, W. L. Prell, and N. J. Shackleton (1984), The orbital theory of Pleistocene climate: Support from a revised chronology of the marine $\mathrm{d}^{18} \mathrm{O}$ Record, in Milankovitch and Climate, Part 1, Series C: Mathematical and Physical Sciences, vol. 126, edited by A. Berger et al., pp. 269-305, D. Reidel, Norwell, Mass.

Kadko, D. C. (1980), A detailed study of some uranium series nuclides at an abyssal hill area near the East Pacific Rise at $8^{\circ} 45^{\prime} \mathrm{N}$, Earth Planet. Sci. Lett., 51, 115-131.

Kawahata, H., A. Suzuki, and H. Ohta (2000), Export fluxes in the western Pacific warm pool, Deep Sea Res. Part I, 47, 2061-2091.

Kienast, M., S. Steinke, K. Stattegger, and S. E. Calvert (2001), Synchronous tropical South China Sea SST change and Greenland Warming during deglaciation, Science, 291, 2132 2134.

Klinkhammer, G. P., and M. R. Palmer (1991), Uranium in the oceans: Where it goes and why, Geochim. Cosmochim. Acta, 55, 1799 1806

Koutavas, A., J. Lynch-Stieglitz, T. M. Marchitto, and J. P. Sachs (2002), El Nino-like pattern in ice age tropical Pacific sea surface temperature, Science, 297, 226-230.

Ku, T.-L., K. G. Knauss, and G. G. Matthieu (1977), Uranium in open ocean: Concentration and isotopic composition, Deep Sea Res., 24, $1002-1017$.

Kumar, N., G. Gwiazda, R. F. Anderson, and P. N. Froelich (1993), ${ }^{231} \mathrm{~Pa} /{ }^{230} \mathrm{Th}$ ratios in sediments as a proxy for past changes in the Southern Ocean productivity, Nature, 362, 45-48.

Kumar, N., R. F. Anderson, R. A. Mortlock, P. N Froelich, P. Kubik, B. Dittrich-Hannen, and M. Suter (1995), Increased biological productivity and export production in the glacial Southern Ocean, Nature, 3778, 675-680.

Lambeck, K., and J. Chappell (2001), Sea level change through the last glacial cycle, Science, 292, 679-686

Lao, Y., R. F. Anderson, and W. S. Broecker (1992), Boundary scavenging and deep-sea sediment dating: Constraints from excess ${ }^{230} \mathrm{Th}$ and ${ }^{231} \mathrm{~Pa}$, Paleoceanography, 7 , $783-798$.

Laws, E. A., P. G. Falkowski, O. J. Smith, H. Ducklow, and J. J. McCarthy (2000), Temperature effects on the export production in the open ocean, Global Biogeochem. Cycles, 14, $1231-1246$.

Lea, D. W., D. K. Pak, and H. J. Spero (2000), Climate impact of late Quaternary equatorial Pacific sea surface temperature variations, Science, 289, 1719-1724.

Loubere, P. (1999), A multiproxy reconstruction of biological productivity and oceanography in 
the eastern equatorial Pacific for the past 30,000 years, Mar. Micropaleontol., 37, $173-198$.

Loubere, P. (2000), Marine control of biological production in the eastern equatorial Pacific Ocean, Nature, 406, 497-500.

Loubere, P. (2001), Nutrient and oceanographic changes in the eastern equatorial Pacific from the last full glacial to the present, Glob. Planet. Change, 29, 77-98

Loubere, P. (2003), Remote vs. local control of changes in eastern equatorial Pacific bioproductivity from the Last Glacial Maximum to the present, Global Planet. Change, 35, 113126.

Loubere, P., F. Mekik, R. Francois, and S. Pichat (2004), Export fluxes of calcite in the eastern equatorial Pacific from the Last Glacial Maximum to present, Paleoceanography, 19, PA2018, doi:10.1029/2003PA000986.

Lyle, M., D. W. Murray, B. P. Finney, J. Dymond, J. M. Robbins, and K. Brooksforce (1988), The record of the late Pleistocene biogenic sedimentation of the eastern tropical Pacific Ocean, Paleoceanography, 3, 39-59.

Lyle, M., F. G. Prahl, and M. A. Sparrow (1992), Upwelling and productivity changes inferred from a temperature record in the central equatorial Pacific, Nature, 355, 812-815.

Mackey, D. J., J. E. O. O'Sullivan, and R. J. Watson (2002), Iron in the western Pacific: A riverine or hydrothermal source for iron in the Equatorial Undercurrent?, Deep Sea Res. Part I, 49, 877-893.

Mangini, A., M. Jung, and S. Laukenmann (2001), What do we learn from peaks of uranium and of manganese in deep sea sediments?, Mar. Geol., 177, 63-78.

Marcantonio, F., R. F. Anderson, S. Higgins, M. Stute, and P. Schloesser (2001), Sediment focusing in the central equatorial Pacific Ocean, Paleoceanography, 16, 260-267.

Martinson, D. G., N. G. Pisias, J. D. Hays, J. Imbrie, T. C. Moore, and N. J. Shackleton (1987), Age dating and the orbital theory of the ice ages: Development of a high-resolution 0 to 30,0000-year chronostratigraphy, Quat. Res., 27, 1-29.

Matsumoto, K., and J. Lynch-Stieglitz (1999), Similar glacial and Holocene deep water circulation inferred from southeast Pacific benthic foraminiferal carbon isotope composition, Paleoceanography, 14, 149-163.

Matsumoto, K., J. L. Sarmiento, and M. A. Brzezinski (2002), Silicic acid leakage from the Southern Ocean: A possible explanation for glacial atmospheric $p \mathrm{CO}_{2}$, Global Biogeochem. Cycles, 16(3), 1031, doi:10.1029/ $2001 \mathrm{~GB} 001442$

McManus, J. F., R. F. Anderson, W. S. Broecker, M. Q. Fleisher, and S. M. Higgins (1998), Radiometrically determined sedimentary fluxes in the sub-polar North Atlantic during the last 14,0000 years, Earth Planet. Sci. Lett., $155,29-43$.

Mekik, F. A., P. W. Loubere, and D. E. Archer (2002), Organic carbon flux and organic carbon to calcite flux ratio recorded in deep-sea carbonates: Demonstration and a new proxy, Global Biogeochem. Cycles, 16(3), 1052 , doi:10.1029/2001GB001634.

Milliman, J. D., K. L. Farnsworth, and C. S. Albertin (1999), Flux and fate of fluvial sediments leaving large islands in the east Indies, J. Sea Res., 41, 97-107.

Mix, A. C., N. G. Pisias, W. Rugh, J. Wilson, A. Morey, and T. K. Hagelberg (1995), Benthic foraminifer stable isotope record from site 849 (0-5 Ma): Local and global climate changes, Proc. Ocean Drill. Program Sci. Results, 138, 371-412.

Mix, A. C., A. E. Morey, N. G. Pisias, and S. W. Hostetler (1999), Foraminiferal faunal estimates of paleotemperature: Circumventing the no-analog problem yields cool ice age tropics, Paleoceanography, 14, 350-359.

Moran, S. B., C.-C. Shen, H. N. Edmonds, S. E Weinstein, J. N. Smith, and R. L. Edward (2002), Dissolved and particulate ${ }^{231} \mathrm{~Pa}$ and ${ }^{230} \mathrm{Th}$ in the Atlantic Ocean: Constraints on intermediate/deep water age, boundary scavenging, and ${ }^{231} \mathrm{~Pa} /{ }^{230} \mathrm{Th}$ fractionation, Earth Planet. Sci. Lett., 203, 999-1014.

Mortlock, R. A., and P. N. Froelich (1989), A simple method for the rapid determination of biogenic opal in pelagic marine sediments, Deep Sea Res., 36, 1415-1426.

Murray, J. W., R. T. Barber, M. R. Roman, M. P. Bacon, and R. A. Feely (1994), Physical and biological controls on carbon cycling in the equatorial Pacific, Science, 266, 58-65.

Murray, R. W., M. Leinen, and A. R. Isern (1993), Biogenic flux of Al to sediment in the central equatorial Pacific Ocean: Evidence for increased productivity during glacial periods, Paleoceanography, 8, 651-671.

Nozaki, Y., and T. Nakanishi (1985), ${ }^{231} \mathrm{~Pa}$ and ${ }^{230} \mathrm{Th}$ profiles in the open ocean water column, Deep Sea Res., 32, 1209-1220.

Nozaki, Y., Y. Horibe, and H. Tsubota (1981), The water column distributions of thorium isotopes in the western North Pacific, Earth Planet. Sci. Lett., 54, 203-216.

Parkin, D. W., and N. J. Shackleton (1973), Trade wind and temperature correlations down a deep-sea core off the Sahara coast, Nature, 245, 455-457.

Patrick, A., and R. C. Thunell (1997), Tropical Pacific sea surface temperature and upper water column thermal structure during the las glacial maximum, Paleoceanography, 12 649-657.

Paytan, A., M. Kastner, and F. Chavez (1996), Glacial to interglacial fluctuations in productivity in the equatorial Pacific as indicated by marine barite, Science, 274, 1355-1357.

Pedersen, T. F. (1983), Increased productivity in the eastern equatorial Pacific during the last glacial maximum $(19,000$ to $14,000 \mathrm{yr}$ B. P.) Geology, 11, 16-19.

Pedersen, T. F., B. Nielsen, and M. Pickering (1991), Timing of late Quaternary productivity pulses in the Panama Basin and implications for atmospheric CO2, Paleoceanography, 6, 657-677.

Pichat, S. (2001), Variations du rapport $\left({ }^{231} \mathrm{~Pa} /{ }^{230} \mathrm{Th}\right)_{\mathrm{xs}, 0}$ et de la composition isotopique du zinc dans des sédiments de l'océan Pacifique équatorial au Quaternaire: Implications pour la productivité biologique et relations avec la thermocline, Ph.D. thesis, 213 pp., Ecole Normale Supérieure de Lyon, Lyon, France.

Pichat, S., C. Douchet, and F. Albarède (2003), Zinc isotope variations in deep-sea carbonates from the eastern equatorial Pacific over the last 175 ka, Earth Planet. Sci. Lett., 210, 167-178.

Rodgers, K. B., B. Blanke, G. Madec, O. Aumont, P. Ciais, and J. Dutay (2003), Extratropical sources of Equatorial Pacific upwelling in an OGCM, Geophys. Res. Lett. 30(2), 1084, doi:10.1029/2002GL016003.

Rosenthal, Y., D. W. Oppo, and B. K. Linsley (2003), The amplitude and phasing of climate change during the last deglaciation in the Sulu Sea, western equatorial Pacific, Geophys. Res.
Lett., $30(8), 1428$, doi:10.1029/ 2002GL016612.

Sarnthein, M., G. Tetzlaff, B. Koopman, K. Walter, and U. Pflaumann (1981), Glacial and interglacial wind regimes over the east subtropical Atlantic and N. W. Africa, Nature, 293, 193-196

Sarnthein, M., K. Winn, J.-C. Duplessy, and M. R. Fontugne (1988), Global variations of the surface ocean productivity in low and mid latitudes: Influence on $\mathrm{CO}_{2}$ reservoirs of the deep ocean and the atmosphere during the last 21,000 years, Paleoceanography, 3, 361-399.

Shimmield, G. B., and N. B. Price (1988), The scavenging of $\mathrm{U},{ }^{230} \mathrm{Th}$, and ${ }^{231} \mathrm{~Pa}$ during pulsed hydrothermal activity at $20^{\circ} \mathrm{S}$, East Pacific Rise, Geochim. Cosmochim. Acta, 52, 669-677.

Shimmield, G. B., J. W. Murray, J. Thomson, M. P. Bacon, R. F. Anderson, and N. B. Price (1986), The distribution and behaviour of ${ }^{230} \mathrm{Th}$ and ${ }^{231} \mathrm{~Pa}$ at ocean margin, Baja California, Mexico, Geochim. Cosmochim. Acta, 50, 2499-2507.

Spero, H. J., and D. W. Lea (2002), The cause of carbon isotope minimum events on glacial terminations, Science, 296, 522-525.

Stephens, M. P., and D. C. Kadko (1997), Glacial-Holocene calcium carbonate dissolution at the central equatorial Pacific seafloor, Paleoceanography, 12, 797-804.

Stott, L., C. Poulsen, S. Lund, and R. Thunell (2002), Super ENSO and global climate oscillations at millennial time scales, Science, 297, $222-226$.

Stracke, A., and E. Hegner (1998), Riftingrelated volcanism in an oceanic post-collisional setting: The Tabar-Lihir-Tanga-Feni (TLTF) island chain, Papua New Guinea, Lithos, 45, 545-560.

Stuiver, M., P. Quay, and H. G. Ostlund (1983), Abyssal water carbon-14 distribution and the age of the world oceans, Science, 219, 849851.

Suman, D. O., and M. P. Bacon (1989), Variations in Holocene sedimentation in the north American basin determined from Th230 measurements, Deep Sea Res., 36, $869-878$.

Taylor, S. R., and S. M. McLennan (1985), The Continental Crust: Its Composition and Evolution, 312 pp., Blackwell, Malden, Mass.

Taylor, S. R., and S. M. McLennan (1995), The geochemical evolution of the continental crust, Rev. Geophys., 33, 241-265.

Toggweiler, J. R., K. Dixon, and W. S. Broecker (1991), The Peru upwelling and the ventilation of the South Pacific thermocline, J. Geophys. Res., 96, 20,467-20,497.

Visser, K., R. Thunell, and M. A. Goni (2004) Glacial-interglacial organic carbon record from the Makassar Strait, Indonesia: Implications for regional changes in continental vegetation, Quat. Sci. Rev., 23, 17-27.

Walter, H.-J., M. M. R. van der Loeff, and H. Hoeltzen (1997), Enhanced scavenging of ${ }^{231} \mathrm{~Pa}$ relative to ${ }^{230} \mathrm{Th}$ in the South Atlantic south of the Polar front: Implications for the use of the ${ }^{231} \mathrm{~Pa} /{ }^{230} \mathrm{Th}$ ratio as a paleoproductivity proxy, Earth Planet. Sci. Lett., 149, 85100 .

Walter, H.-J., M. M. R. van der Loeff, and R. François (1999), Reliability of the ${ }^{231} \mathrm{~Pa} /{ }^{230} \mathrm{Th}$ activity ratio as a tracer for bioproductivity of the ocean, in Use of Proxies in Paleoceanography: Examples From the South Atlantic, edited by G. Fischer and G. Wefer, pp. 393-408, Springer-Verlag, New York. 
Walter, H.-J., W. Geibert, M. M. R. van der Loeff, G. Fischer, and U. Bathmann (2001), Shallow vs. deep-water scavenging of ${ }^{231} \mathrm{~Pa}$ and ${ }^{230} \mathrm{Th}$ in radionuclide enriched waters of the Atlantic sector of the Southern Ocean, Deep Sea Res., 48, 471-493.

Yu, E.-F., R. François, and M. P. Bacon (1996), Similar rates of modern and lastglacial ocean thermohaline circulation inferred from radiochemical data, Nature, $379,689-694$.
Yu, E.-F., R. François, M. P. Bacon, and A. P. Fleer (2001), Fluxes of ${ }^{230} \mathrm{Th}$ and ${ }^{231} \mathrm{~Pa}$ to the deep sea: Implications for the interpretation of excess ${ }^{230} \mathrm{Th}$ and ${ }^{231} \mathrm{~Pa}^{230} \mathrm{Th}$ profiles in sediments, Earth Planet. Sci. Lett., 191, 219-230.

F. Albarède, Laboratoire de Sciences de la Terre, Ecole normale supérieure de Lyon, 46, allée d'Italie, F-69364 Lyon cedex 7, France.
S. Brown Leger and R. François, Department of Marine Chemistry and Geochemistry, Woods Hole Oceanographic Institution, Woods Hole, MA 02543, USA.

J. F. McManus and Kenneth W. W. Sims, Department of Geology and Geophysics, Woods Hole Oceanographic Institution, Woods Hole, MA 02543, USA.

S. Pichat, Department of Earth Sciences, University of Oxford, Parks Road, Oxford OX1 3PR, UK. (sylvainp@earth.ox.ac.uk) 